\title{
Experimental Study on the Fine Structure of Chicken Liver Parenchyme with Special References to Extra- sinusoidal Macrophages and Sinusoidal Blood Cells. Part 1. Sinusoidal Cells and Macrophages in the Normal and India Ink-Perfused Livers
}

\author{
Masako OHATA and Toshio ITo \\ Department of Anatomy (Prof. K. UchidA and Prof. T. ITo), Teikyo University School of Medicine, \\ Tokyo, Japan
}

Received February 3, 1986

\begin{abstract}
Summary. The chicken livers were electron microscopically observed under a normal condition and after an intravenous India ink perfusion. Kupffer cells and sinusoidal endothelial cells commenced to endocytose India ink particles in the earliest stages $(15 \mathrm{~min})$ after purfusion. The attachment of the particles to the cell surface occurred only in the Kupffer cells, which actively took up the particles with coated caveolae. In the endothelial cells the particles were ingested by pinocytosis in the perikaryon and deposited in the macropinocytic vacuoles of Wisse. In Kupffer and endothelial cells, the particles were stored most abundantly at $30 \mathrm{~min}$ and $4 \mathrm{hr}$ after perfusion, respectively. At $48 \mathrm{hr}$, the vacuoles containing the particles were decreased in number and size, while mitotic figures were revealed in the Kupffer cells. Ito cells occasionally ingested in later stages $(4$ and $48 \mathrm{hr})$ a few carbon particles; they underwent no mitotic division.

Extrasinusoidal macrophages scattered in the parenchyme and phagocytic reticular cells (macrophages) in the lymphoid tissues exhibited phagocytic activity only in later stages (1-4 hr). In $48 \mathrm{hr}$ af ter the perfusion both cells began to store amounts of the particles in their vacuoles. This delayed phagocytic activity may be ascribed to the location of the cells separated from the sinusoid by the endothelium. Some solitary macrophages projecting a long process into the sinusoid took up the particles at earlier stages. At $48 \mathrm{hr}$, several mitotic divisions took place in the phagocytic reticular cells of the lymphoid tissue, while no mitotic divisions were found in the solitary macrophages in the parenchyme. After the ink perfusion, migration of solitary macrophages into the sinusoid was accelerated and images indicating their transformation into Kupffer cells were frequently detected. It was concluded that the Kupffer cells maintain their necessary number not only by their selfproliferation but also by replenishment from the extrasinusoidal solitary macrophages scattered in the hepatic parenchyme, which in turn are replenished from the phagocytic reticular cells in the lymphoid tissue capable of mitotic proliferation.
\end{abstract}

Although a number of theories have been proposed with respect to the origin of Kupffer cells and their renewal or replenishment (see Discussion), this problem has not been settled until today. In our previous electron microscope study it was demonstrated that the chicken liver parenchyme contained many macrophages both in the Disse's 
space and between the hepatocytes, some showing profiles of apparent migration from the Disse's spaces into the sinusoid through the endothelial lining (ОнатA et al., 1982). This finding in the avian liver suggests the possibility that macrophages in the liver parenchyme may also participate in the replenishment of Kupffer cells by migration into the sinusoid. The present study was attempted to further clarify this point, using chicken livers under the normal and reticuloendothelial system (RES)-stimulated conditions induced by the intravenous perfusion of India ink.

\section{MATERIALS AND METHODS}

Ten chickens (male white Leghorn) weighing about 1,500-2,500 g were used.

RES stimulation by India ink perfusion: Chickens were intravenously perfused with a large dose of India ink, and fixed after 15, $30 \mathrm{~min}, 1,4$ and $48 \mathrm{hr}$ ( 2 days). The application of such a large dose of India ink seems to stimulate the RES, since mitotic figures and images of migration were frequently found in the intraparenchymal macrophages and Kupffer cells. The livers were fixed in situ by perfusion with a fixative containing $2.5 \%$ glutaraldehyde and $0.1 \mathrm{M}$ cacodylate $(\mathrm{pH} 7.4)$. The livers were then excised and cut minute tissue pieces to be further fixed in the same fixative. After $2 \mathrm{hr}$ fixation, they were rinsed several times in a cold buffer and left overnight in the same buffer. They were postfixed in a $1.33 \% \mathrm{OsO}_{4}$ solution for $90 \mathrm{~min}$. Following dehydration in an ethanol series, the tissues were embedded in Quetol. Ultrathin sections made by a Porter-Blum Ultra-Microtome MT2-B were stained with saturated uranyl acetate and Sato's lead solution, and examined with a JEM-100C electron microscope.

\section{RESULTS}

\section{A. Hepatic parencyme in normal control chickens}

\section{Characteristic structures of the chicken liver}

The hepatic cell cords constituting the liver parenchyme or hepatic lobules in the chicken agree in structure with terminal portions of the tubular glands (Fig. 1): Several conical hepatocytes were radially arranged around a small central bile canalicule; their apical narrow surfaces with short microvilli bordered the bile canalicule, while the wide basal surfaces with long irregular microvilli bordered the Disse's space. This space was separated from the sinusoid by the endothelial lining, communicating with several interhepatocytic spaces.

The cytoplasmic matrix of the hepatocytes was characterized by its high electron density and densely packed, abundant, large mitochondria (Fig. 1), probably reflecting the high metabolic activity of avian hepatocytes (OHAta et al., 1982).

\section{Sinusoidal endothelium}

The endothelial cells formed the partition between the sinusoidal lumen and the narrow Disse's space. They were composed of a spindle-shaped cell body (perikaryon) containing a nucleus and the majority of the organelles and membraneous cytoplasmic extension covering the major part of the sinusoidal lining (Fig. 1). The latter portion of the cell consisted alternately of thicker portions containing a few organelles, and thinner portions devoid of these and penetrated by fenestrae or pores which were mostly clus- 
tered to form sieve plates. In the chicken, however, a clear morphological distinction between the thicker and thinner portions of the sinusoidal endothelium was often difficult. Coated pits (caveolae) and vesicles were found relatively frequently along the luminal plasma membrane of the endothelial cells.

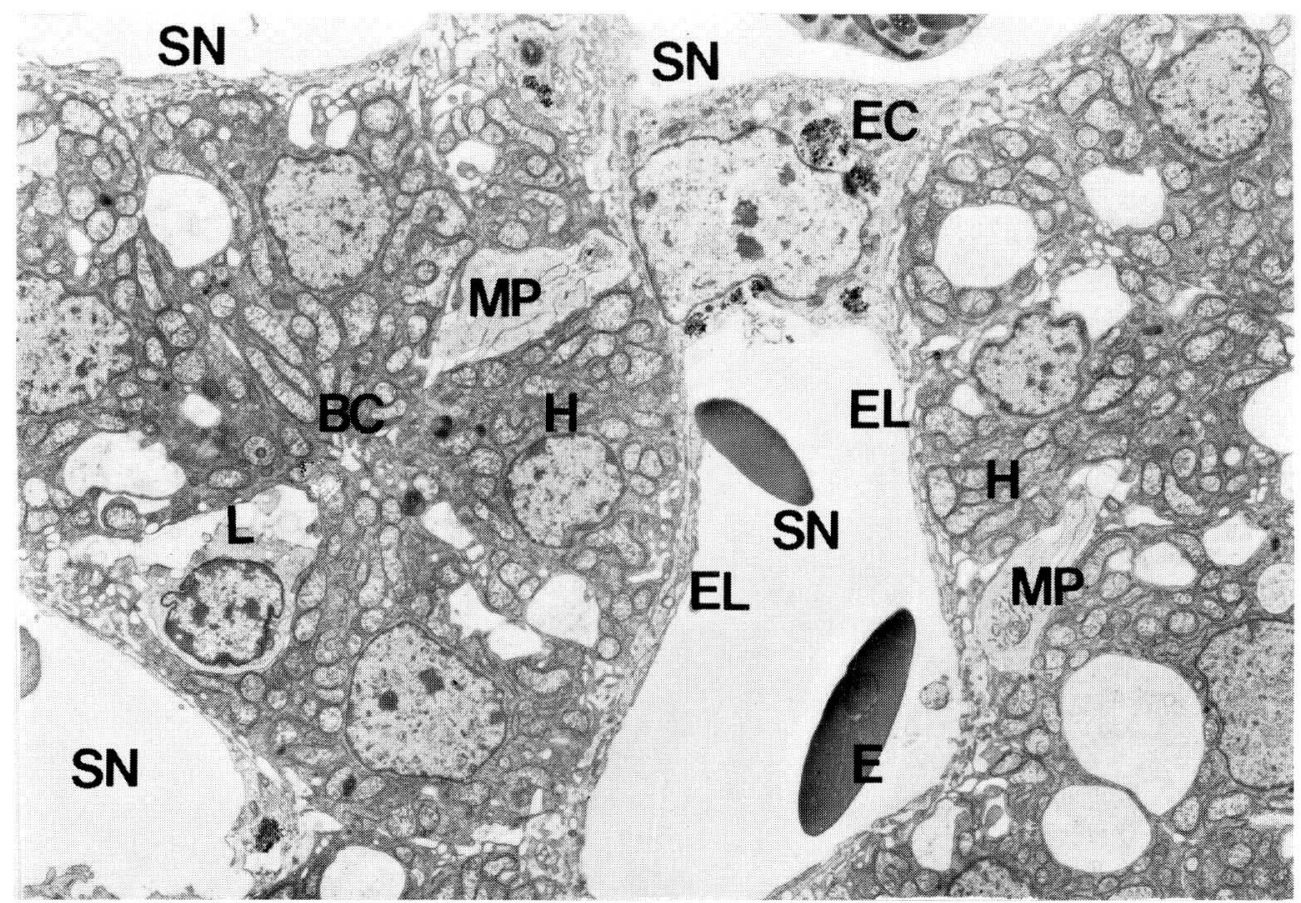

Fig. 1. Chicken liver parenchyme showing the appearance of the terminal portion of a tubular gland. Conical hepatocytes $(H)$ packed by large mitochondria surround a small bile canalicule $(B C)$. An endothelial perikaryon $(E C)$ contains vacuoles filled with India ink particles at $4 \mathrm{hr}$ after India ink perfusion. $E L$ endothelial lining of the sinusoid (SN), E erythrocyte, $L$ lymphocyte, $M P$ solitary macrophages in the interhepatocytic space, $P S$ Disse's spaces. $\quad \times 3,300$

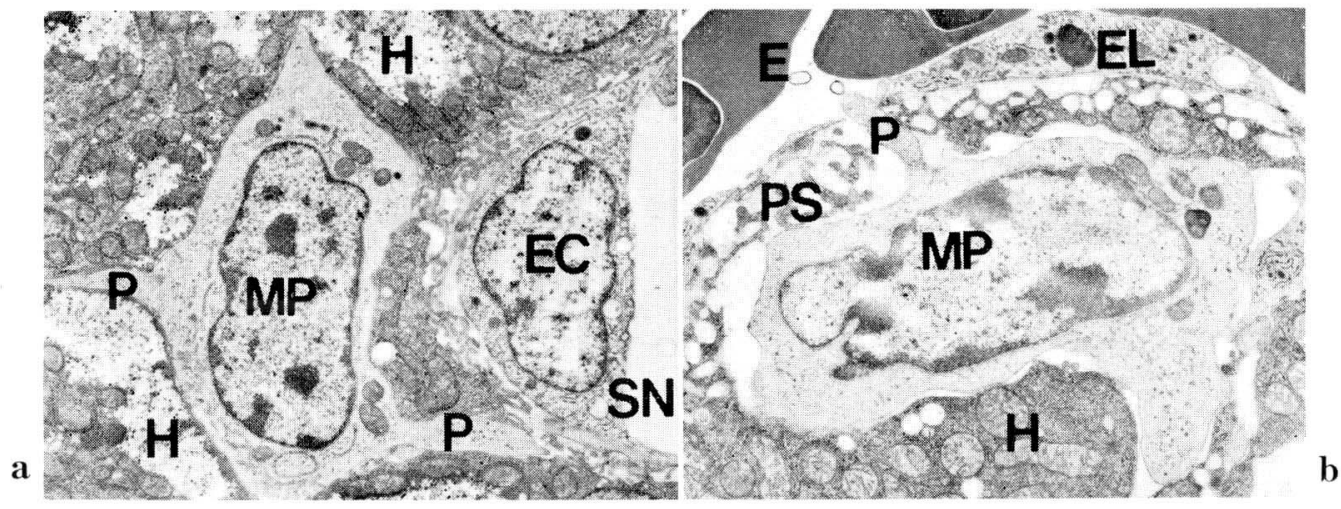

Fig. 2. a and b. Solitary macrophages (MP) in chicken liver parenchyme, located between the hepatocytes $(H)$ or in the Disse's spaces $(P S)$. They are characterized by large mitochondria, sparse small lysosomes, short cisterns of RER and many free ribosomes and project cytoplasmic processes $(P)$ between hepatocytes (in a), into the Disse's space or into the sinusoid (SN) (in b). $H$ hepatocytes, $E L$ endothelial lining of sinusoid $(S N), E$ erythrocytes. Normal conditions. a: $\times 4,600, \mathrm{~b}: \times 6,000$ 


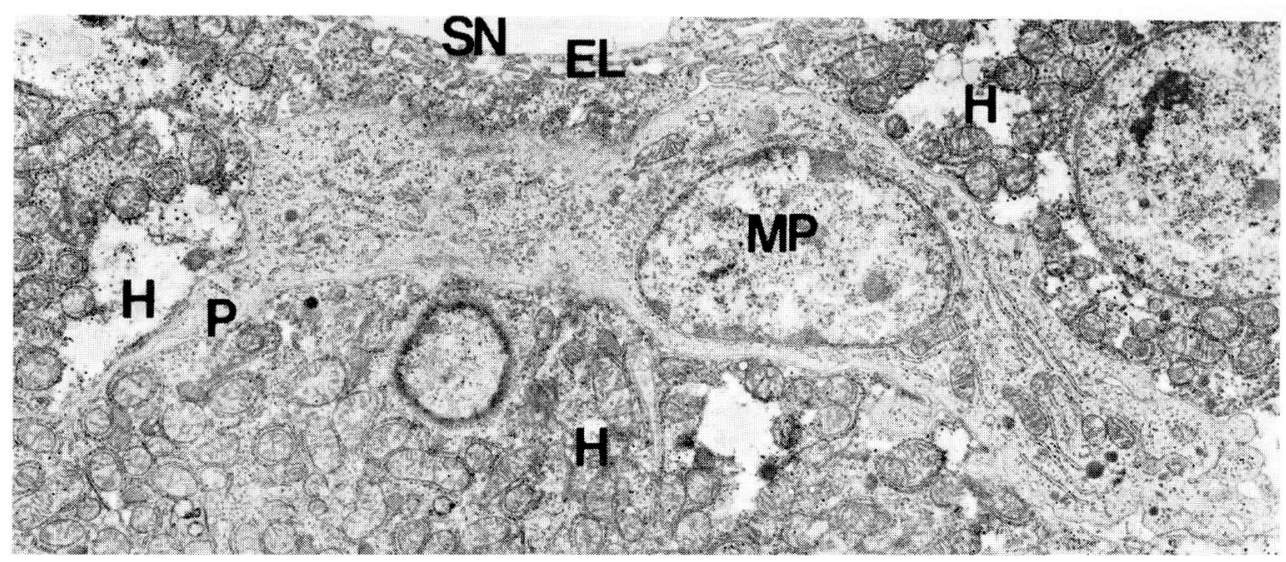

Fig. 3. Highly differentiated solitary macrophage $(M P)$, elongated between hepatocytes $(H)$ and containing numerous cisterns of RER, ribosomes, large mitrochondria and lysosomes. $E L$ endothelial lining of the sinusoid $(S N), P$ cytoplasmic process of the macrophage. Normal conditions. $\times 5,400$

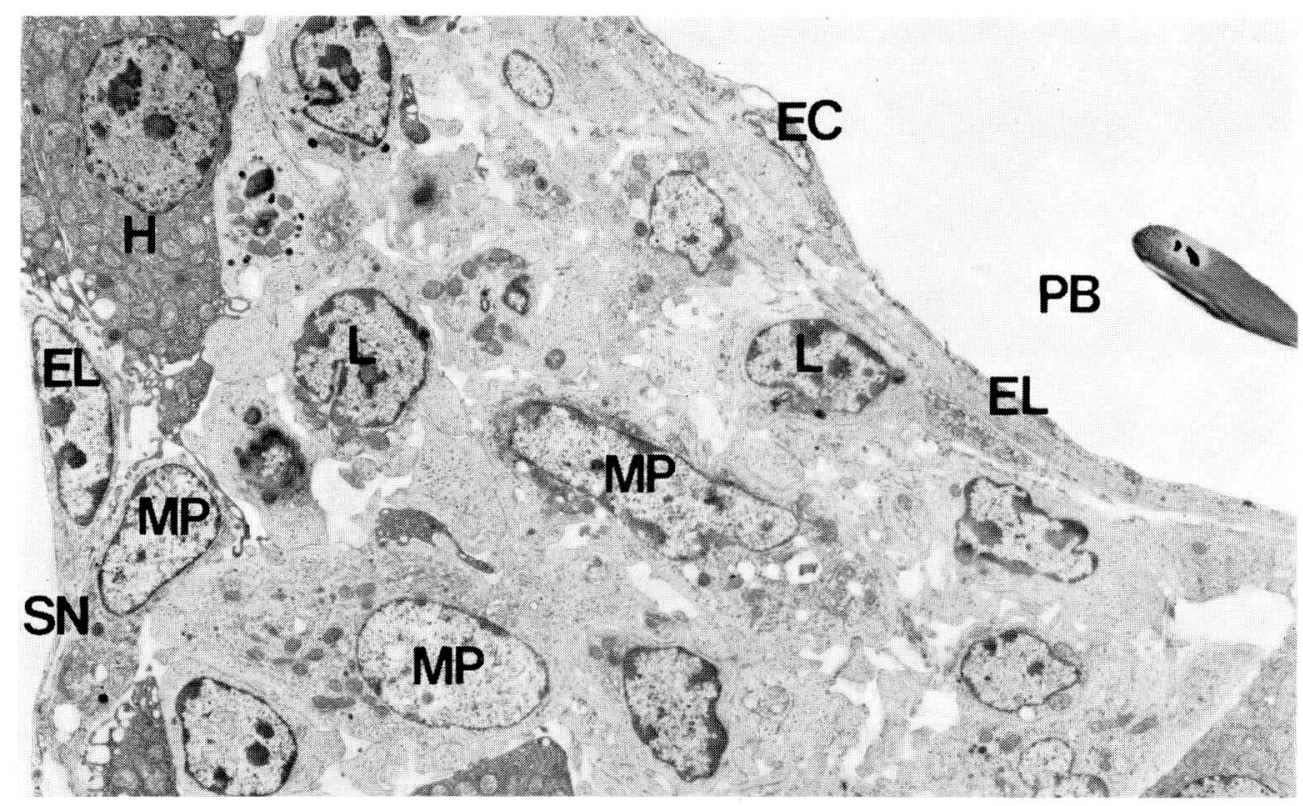

Fig. 4. Lymphoid tissue spreading from the Glisson's sheath on the right side containing a portal branch $(P B)$ and toward the hepatic parenchyme on the left side. EC endothelial cell, EL endothelial lining, $H$ hepatocyte, $L$ lymphocyte, $M P$ macrophage (phagocytic reticular cell), SN sinusoid in hepatic parenchyme. Normal conditions. $\times 3,600$

The cytoplasm of the endothelial cells was generally of low electron density and relatively rich in organelles. As to the cell organelles, detailed descriptions have been given in our previous paper (Oната et al., 1982).

\section{Kupffer cells}

The Kupffer cells were irregular-shaped cytoplasm-rich cells containing numerous organelles. They strongly bulged out from the endothelial lining into the sinusoidal 
lumen. In contrast to the smooth sinusoidal endothelial cells, they protruded numbers of variable-shaped pseudopodia into sinusoid. The Kupffer cell cytoplasm appeared moderately electron dense, containing many organelles, especially numbers of lysosomes and mitochondria, the latter being larger than those in the endothelial and Ito cells. Along the plasma membrane, coated caveolae and vesicles occurred in considerable numbers, while smooth surfaced ones were almost lacking.

\section{Ito cells (fat-storing cells)}

Ito cells were located in the Disse's space, being separated from the sinusoid by the endothelial lining. Typical Ito cells filled with many lipid droplets could be found only rarely in the chicken livers examined in the present study. The lipid contents of the Ito cells varied strikingly from chicken to chicken. Subendothelial processes of Ito cells extending just subjacent to the endothelial lining of the sinusoid have been occasionally detected, and they also often contained lipid droplets (Fig. 7).

\section{Extrasinusoidal macrophages}

Confirming our previous findings (OHATA et al., 1982), the present observation demonstrated occurrence of the extrasinusoidal macrophages scattered in the parenchyme of chicken livers (Fig. 1). They were characterized by large mitochondria, sparse small lysosomes, numerous polysomes and short cisternae of the rough endoplasmic reticulum (RER) scattered in the electron lucent cytoplasm (Fig. 2a, b). They were distributed in the interhepatocytic space or in the Disse's space either solitarily or in small groups. Possesing a round or oval nucleus, they often protruded cytoplasmic processes into the interhepatocytic or Disse's space, which sometimes extended through the endothelium into the sinusoidal lumen (Fig. $2 \mathrm{~b}$ ). The well-developed RER in the cells may probably speak for the differentiation or maturation of these macrophages (Fig. 3).

\section{Lymphoid tissue}

The lymphoid tissues in the chicken liver were mainly found in the Glisson's sheath, and partly spread into the parenchyme to come in contact with hepatocytes and sinusoids. They were mostly of the infiltration type, as cells of the nodular type were rather rare, if at all present; a germinal center was lacking.

The lymphoid tissues probably of the infiltration type, as shown in Figure 4, were composed of two types of cells, i.e., lymphocytes and reticular cells. Lymphocytes have a round or oval nucleus characterized by conspicuous heterochromatin masses along the nuclear membrane. The cytoplasmic layer surrounding the nucleus is relatively narrow and contains only polysomes, dispersed in the cytoplasm, and a few relatively large, round mitochondria gathered mostly on one side of the nucleus. Another type of cell or a reticular cells has an oval or elongate nucleus with less conspicuous heterochromatin masses. They were cytoplasm-rich cells with an irregular outline, and contained numerous mitochondria as large as those in the lymphocyte, variable numbers of short cisterns of the RER, free polysomes, small lysosomes and occasionally small vacuoles (Fig. 4).

\section{B. Changes induced by India ink perfusion}

Kupffer cells and sinusoidal endothelial cells

Fifteen to $30 \mathrm{~min}$ after the intravenous perfusion of India ink, or even earlier, India ink particles were adsorbed by the sinusoidal surface of the Kupffer cells. Some of the particles were adhering also to the surface, facing the Disse's space (Fig. 5, 7). A small 


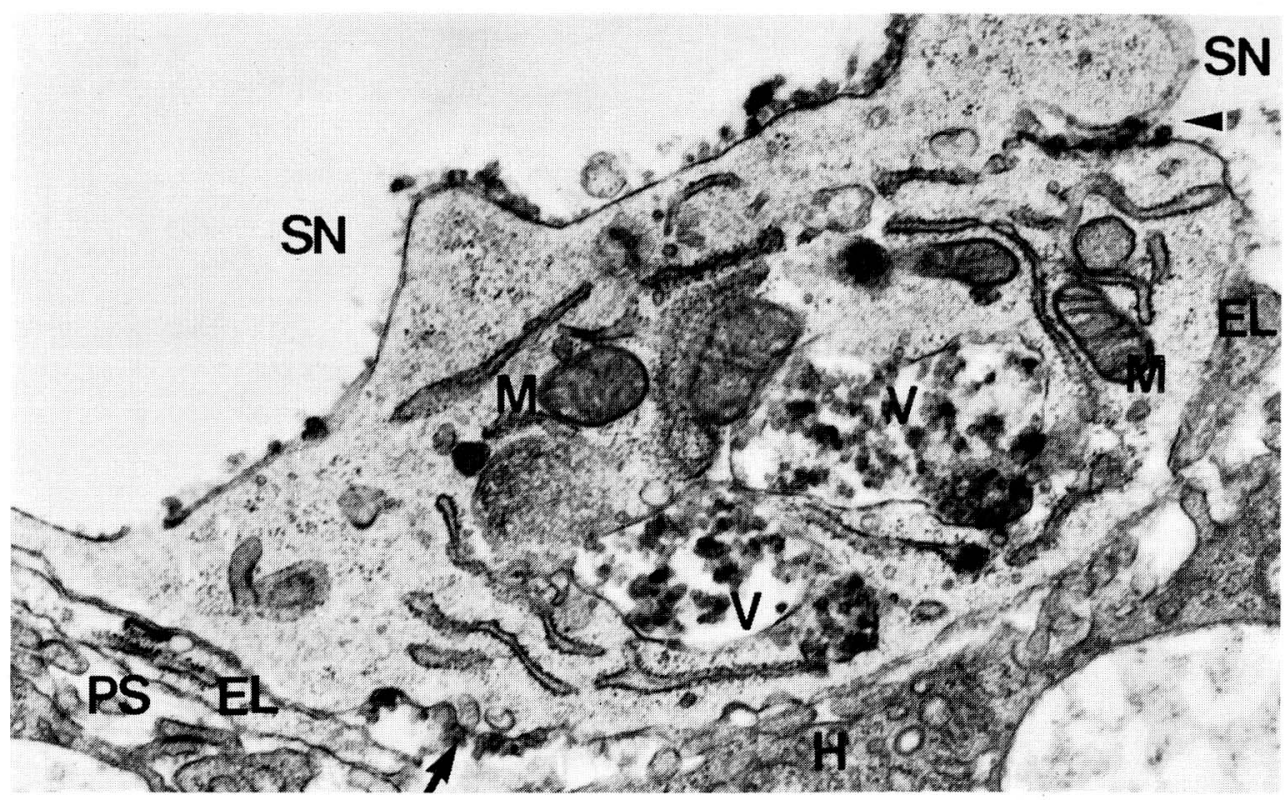

Fig. 5. Kupffer cell, $30 \mathrm{~min}$ after intravenous India ink perfusion. Carbon particles adhere both to the sinusoidal and perisinusoidal surfaces (arrow) of the Kupffer cell. On the light hand, a deep indentation (arrowhead) of the plasma membrane penetrates into the interior, containing the particles which probably are stored in the large vacuoles $(V)$ in the endoplasm. Welldeveloped cisterns of RER and mitochondria $(M)$ are seen. The distinct ectoplasmic layer contains only polysomes. EL endothelial lining connected with the Kupffer cell. $H$ hepatocyte, $P S$ Disse's space, $S N$ sinusoid. $\times 22,000$

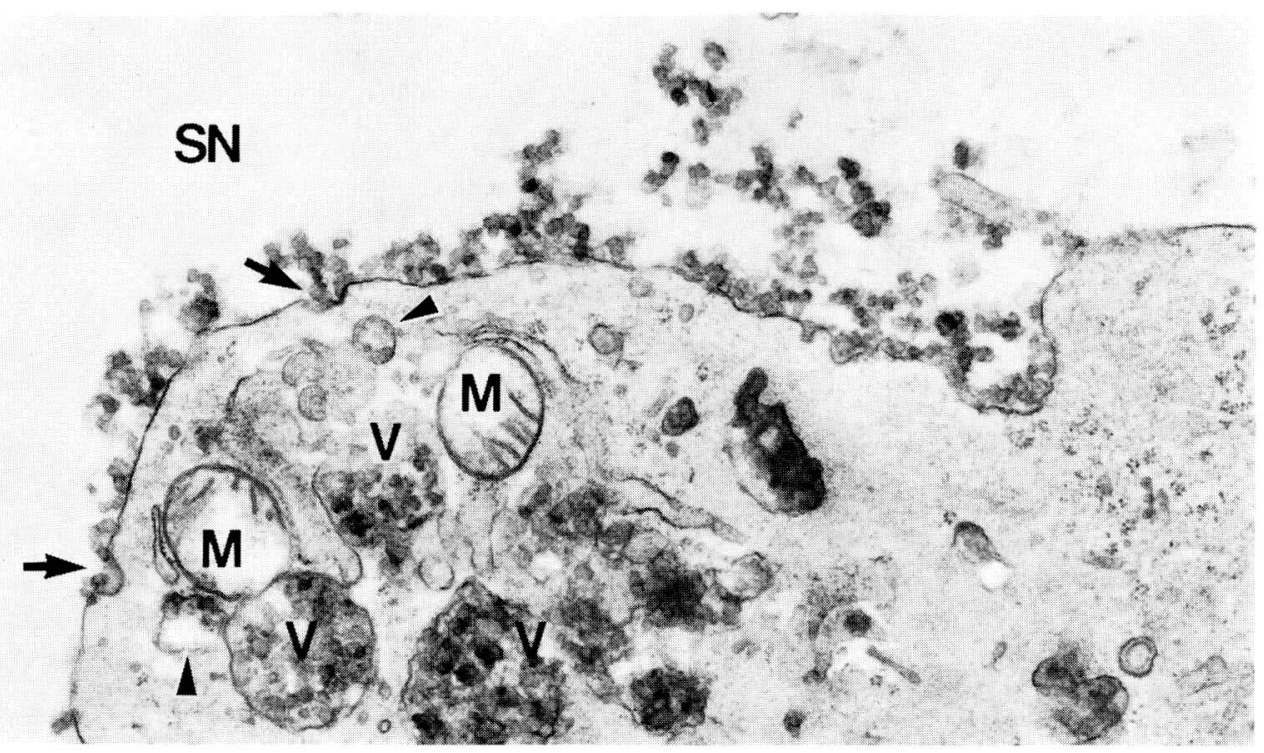

Fig. 6. Apart of the sinusoidal surface of a Kupffer cell, $30 \mathrm{~min}$ after India ink perfusion. Some of the carbon particles adhering to the sinusoidal surface are taken up in coated pits (arrows) and pinched off into pinocytic vesicles containing the particles (arrowheads), which then will fuse to large particle-filled vacuoles $(V) . \quad M$ mitochondria, SN sinusoid. $\quad \times 22,000$ 
part of the particles on the sinusoidal surface were taken up by bristle-coated pits (caveolae) and then pinched off into pinocytic vesicles of variable sizes (Fig. 6). On the other hand, the major part of the particles was contained in certain plasma membrane indentations of variable widths and lengths which penetrated deeply into the cytoplasm through the ectoplasmic layer (Fig. 5, 7). At $30 \mathrm{~min}$, a large quantity of particles was stored in membrane-bound vacuoles of variable sizes and shapes in the endoplasm of the Kupffer cells, which were considered to be profiles of a labyrinth of canalicules with expansions and constrictions (Fig. 8). The amounts of particles stored in the Kupffer cells conspicuously varied from cell to cell. Mitochondria, lysosomes and polysomes were distributed among the particle-containing vacuoles. There were occasional lysosomes ingesting particles. The ectoplasm was clearly distinguished as a homogeneous layer, devoid of organelles, though some ribosomes, pseudopodia did protrude from the ectoplasm and were remarkably diminished. Worm-like structures could not be recognized during this period. At 4 and $48 \mathrm{hr}$ after India ink perfusion, the particlecontaining vacuoles gradually diminished (Fig. 9), and recovery of the worm-like structures was noticed (Fig. 9). At $48 \mathrm{hr}$, mitotic figures of the Kupffer cells were occasionally detected in the sinusoid. They had few pseudopodia, and were rounded in shape; some were elongated (Fig. 10). The organelles tended to be displaced in the peripheral zone or two poles of the cell, and vacuoles containing India ink particles were occasionally visible among them (Fig. 10).

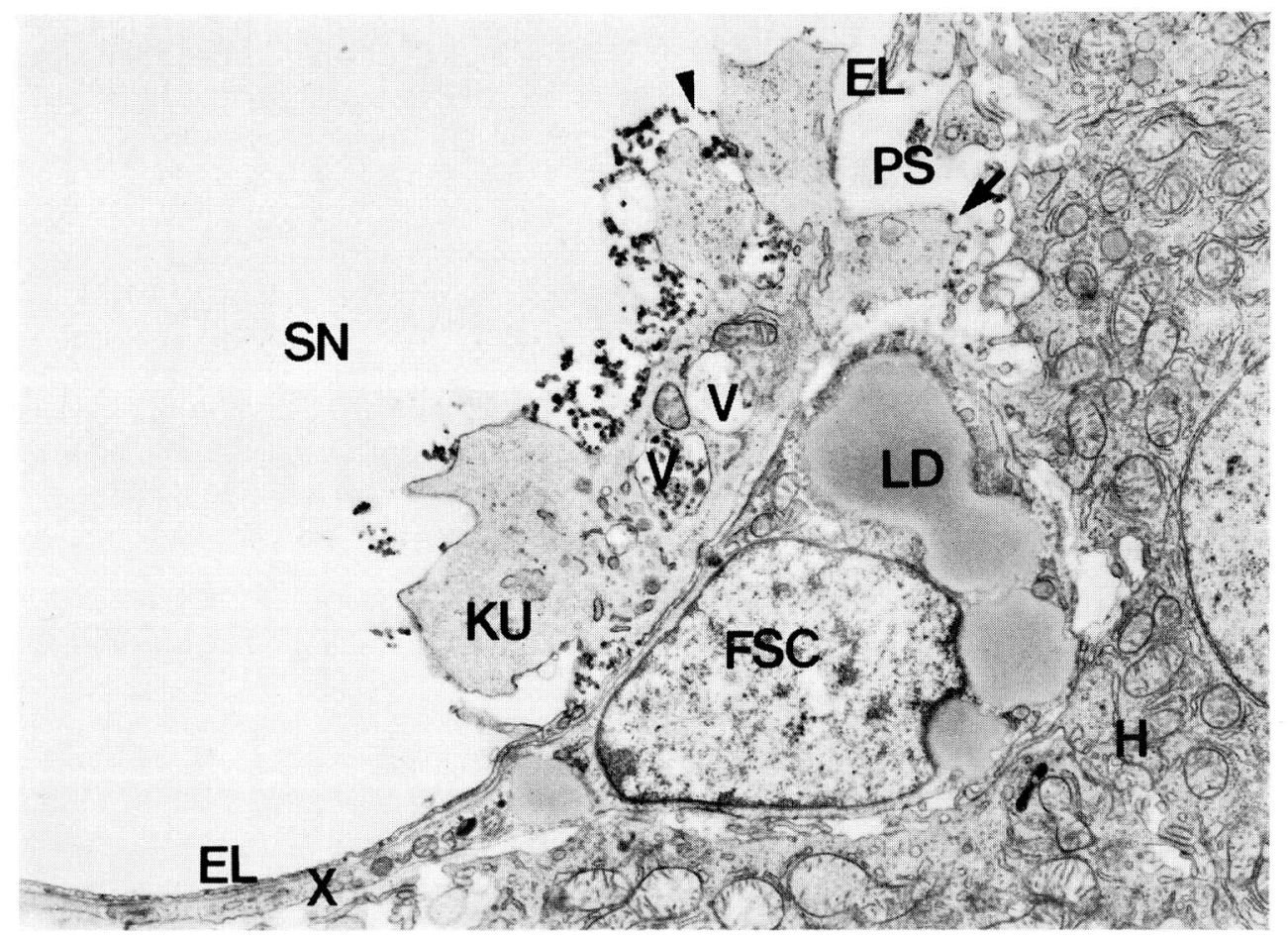

Fig. 7. Kupffer cell $(K U), 30 \mathrm{~min}$ after India ink perfusion. The carbon particles adhere to its sinusoidal and perisinusoidal surfaces (arrow). In the top right corner a deep indentation (arrowhead) penetrates into the interior to transport the particles into the vacuoles $(V)$. An Ito cell (FSC) in the Disse's spaces (PS) contains several lipid droplets ( $L D)$ and projects a process $(X)$ closely along the endothelial lining $(E L)$ of the sinusoid $(S N)$. The Ito cell contains no particle-containing vacuoles. $H$ hepatocyte. $\times 8,000$ 


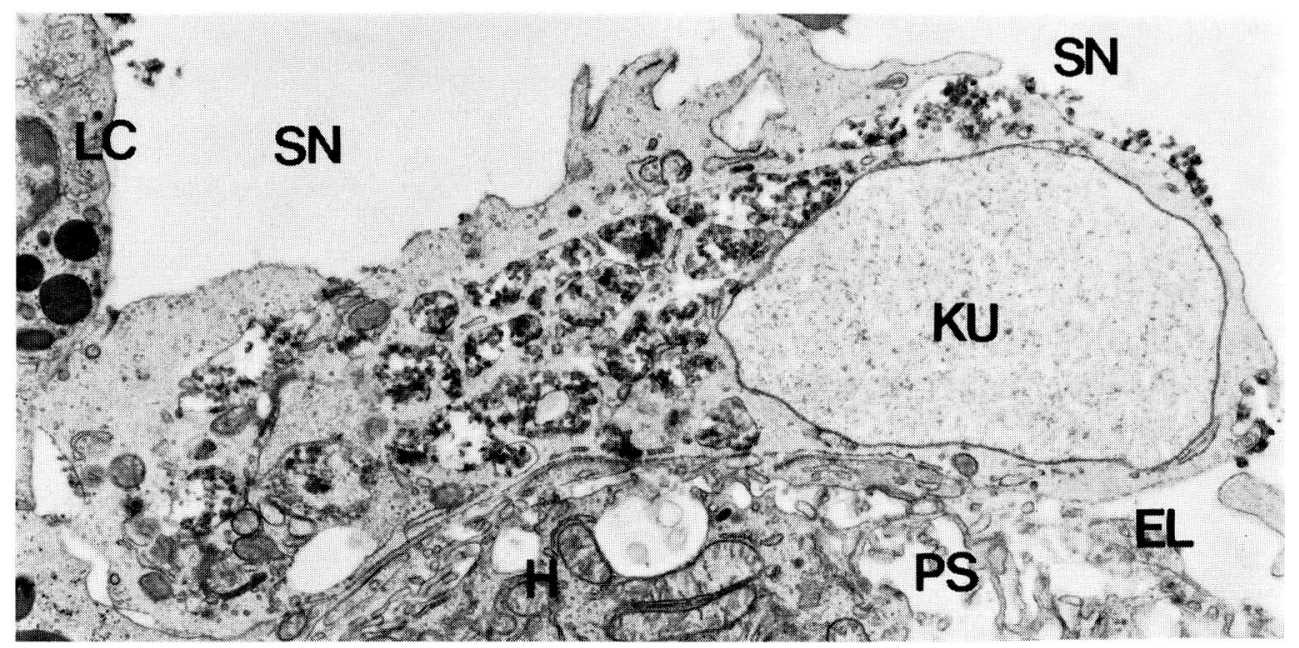

Fig. 8. Kupffer cell $(K U), 30 \mathrm{~min}$ after India ink perfusion. Numerous vacuoles filled with the carbon particles fill up the endoplasm, among which mitochondria and lysosomes are seen. The ectoplasmic layer is distinct; pseudopodia are strikingly diminished. EL endothelial lining, $H$ hepatocyte, $L C$ leucocyte in sinusoid $(S N), P S$ Disse's spaces. $\quad \times 8,000$

India ink uptake by the sinusoidal endothelial cells started as early as the Kupffer cells' action without, however, any attachment of the particles to the plasma membrane. As shown in Figure 11, a few particles taken up by pinocytic mechanism were visible at $30 \mathrm{~min}$ after the perfusion of India ink; they were then ingested in the macropinocytic vacuoles (WISse, 1972) in the perikaryon. At $1 \mathrm{hr}$ after perfusion, a similar finding was revealed in the perikaryon, although the amount of particles contained in each macropinocytic vacuole was not yet large (Fig. 12). After this period, however, the particles stored in the vacuoles were gradually increased (Fig. 1), and at $4 \mathrm{hr}$ the vacuoles, filled up with the particles were so enlarged as to occupy a wide area of the perikaryonal cytoplasm (Fig. 13). In this stage of India ink endocytosis, the lysosomes were recognized to contain some particles. At $48 \mathrm{hr}$, the endothelial cells holding such vacuoles in their perikarya became rare (Fig. 14), although the Kupffer cells generally contained a small number of the particle-filled vacuoles. Through the stages, endothelial cells showed neither mitotic figures nor a tendency to transform into Kupffer cells.

\section{Lymphoid tissues and solitary macrophages}

As Figure 15 indicates, a solitary macrophage was found in the interhepatocytic space at $4 \mathrm{hr}$ after the intravenous perfusion of India ink. Its cytoplasm revealed a considerable number of tortuous cisterns of the RER and a medium-sized vacuole containing India ink particles close to the nucleus, an indication of endocytic activity. At $30 \mathrm{~min}$ after the perfusion of India ink, however, the majority of solitary macrophages within the lobule had not yet taken up particles, provided they were shut up from the sinusoid by an intact endothelial lining. By contrast, if they sent out a cytoplasmic process through a pore in the endothelial lining into the sinusoid, particles in the sinusoid were taken up as early as 20 or 30 min after perfusion, entering into the process to be stored in the vacuole and then transported to the cell body located in the lobule (Fig. 16). Some particles were ingested also into the lysosomes.

At $48 \mathrm{hr}$, the intralobular solitary macrophages even without a transendothelial cytoplasmic process stored particles in their remarkably large vacuoles (Fig. 17). 


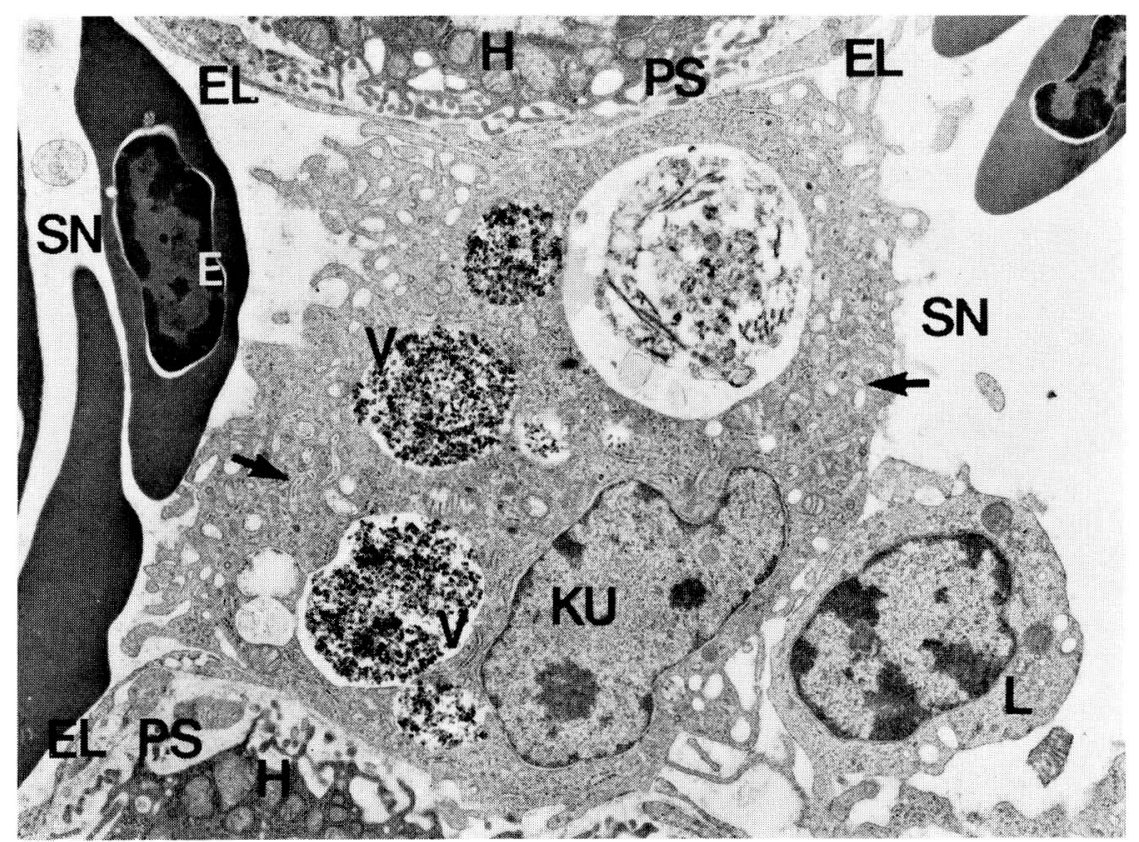

Fig. 9. Kupffer cell ( $K U), 48 \mathrm{hr}$ after India ink perfusion. Several vacuoles $(V)$ filled with the carbon particles are seen in the endoplasm. Pseudopodia are increased. Worm-like structures (arrows) characterized by the median dense line have recovered. EL endothelial lining of the sinusoid $(S N), E$ erythrocyte, $H$ hepatocyte, PS Disse's spaces. $\quad \times 6,600$

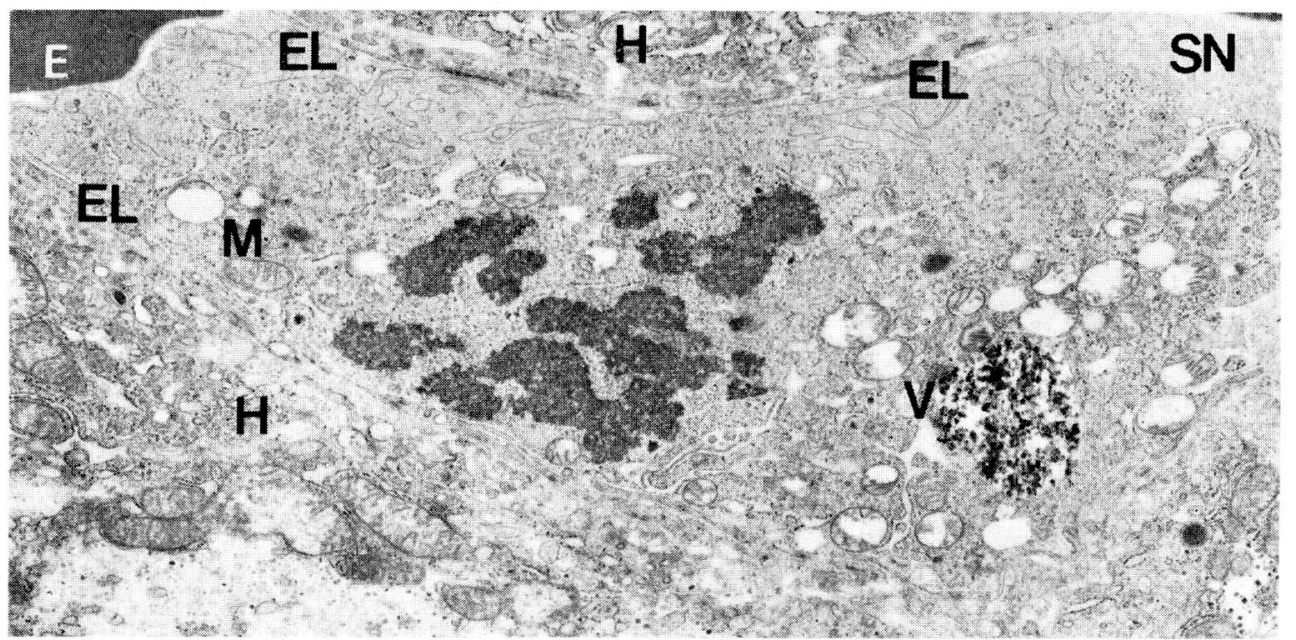

Fig. 10. Mitosis of a Kupffer cell in the sinusoid (SN), $48 \mathrm{hr}$ after India ink perfusion. Cell organelles and a large vacuole $(V)$ filled will the carbon particles are located to both opposite poles of the elongated cell body. $E$ erythrocyte in the sinusoid, $E L$ endothelial lining, $H$ hepatocyte, $M$ mitochondria. $\times 8,800$ 


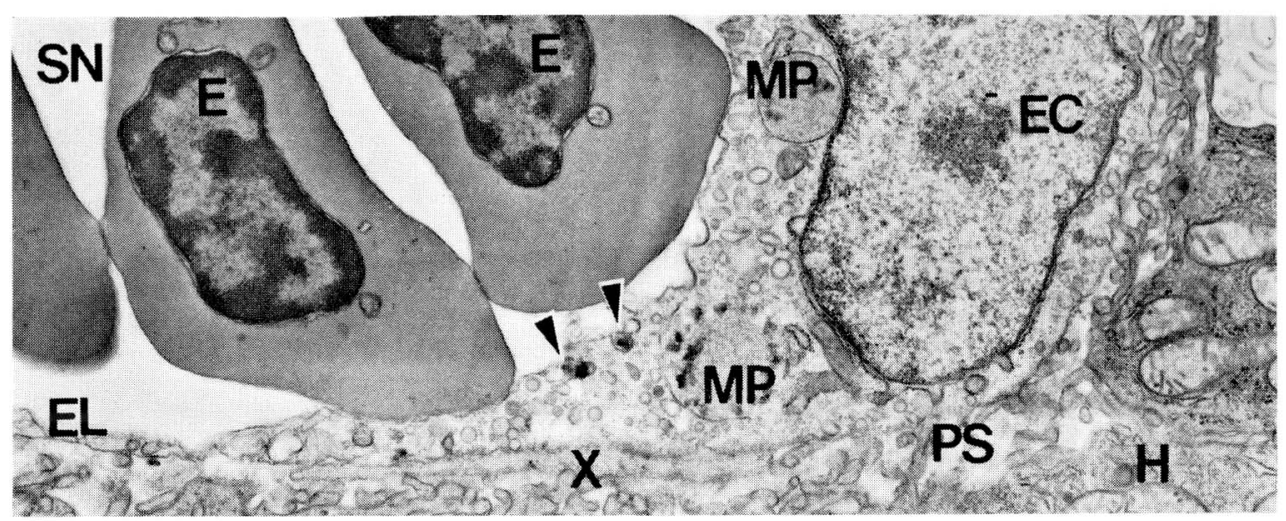

Fig. 11. Endothelial perikaryon (EC), $30 \mathrm{~min}$ after India ink purfusion. Carbon particles taken up by the micropinocytic mechanism (arrowheads) are contained in the macropinocytic vacuoles (MP, WISSE). E erythrocyte in sinusoid (SN), EL endothelial lining, $H$ hepatocyte, $P S$ Disse's spaces, $X$ subendothelial process of Ito cell. $\times 11,700$

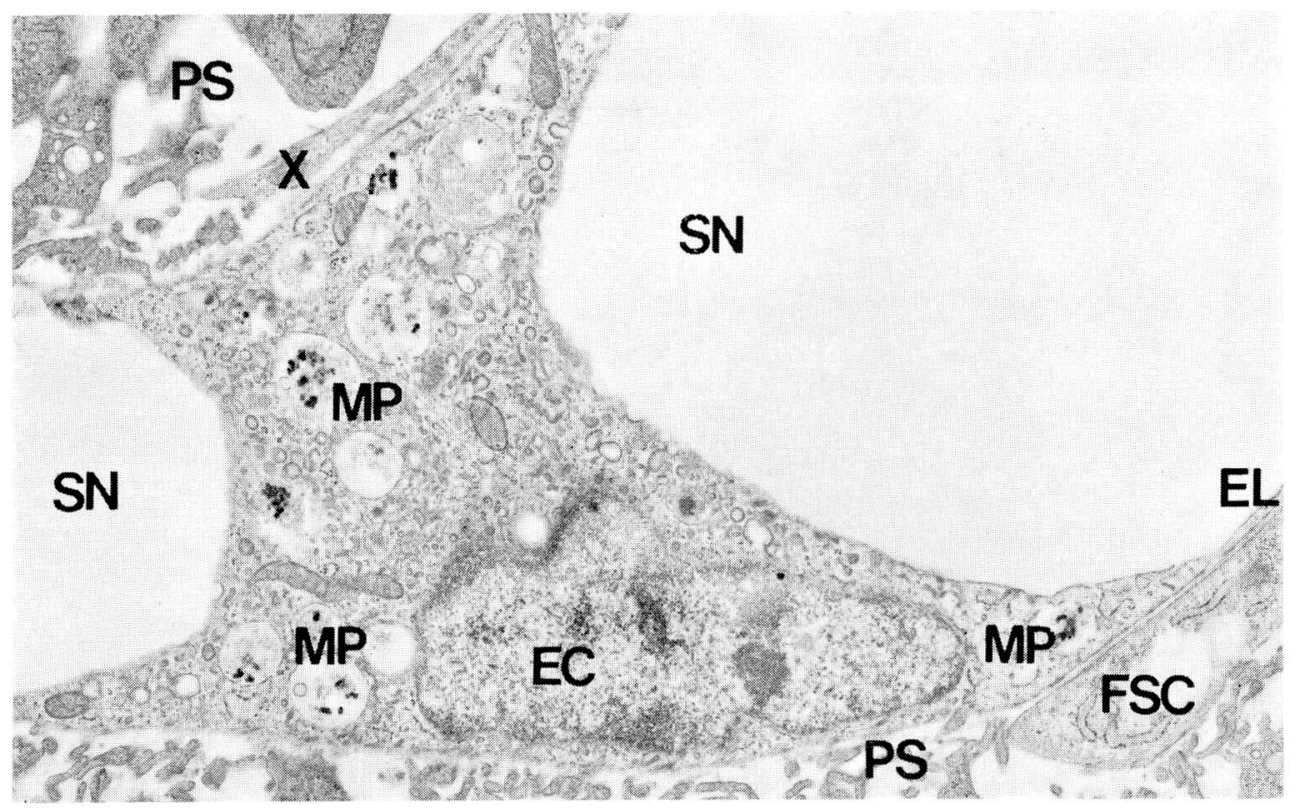

Fig. 12. Endothelial perikaryon (EC), $1 \mathrm{hr}$ after India ink perfusion. Macropinocytic vacuoles $(M P)$ are strikingly increased, storing considerable numbers of carbon particles. $E L$ endothelial lining of the sinusoid (SN), FSC Ito cell in Disse's spaces (PS), $X$ subendothelial process of Ito cell. $\times 10,000$

The migration of the solitary macrophages through the endothelium into the sinusoid appeared to accelerate after the perfusion of India ink. A macrophage depicted in Figure 18 represented one which was almost entirely dislocated through a large pore of the endothelium into the sinusoid at 30 min after India ink perfusion and which is characterized by pseudopodia, numerous lysosomes and large mitochondria. This macrophage was thought to have already obtained the property of a Kupffer cell to adsorb India ink particles into the plasma membrane, though none of them are ingested in the cytoplasm. Another example of a solitary macrophage is shown in Figure 19. 


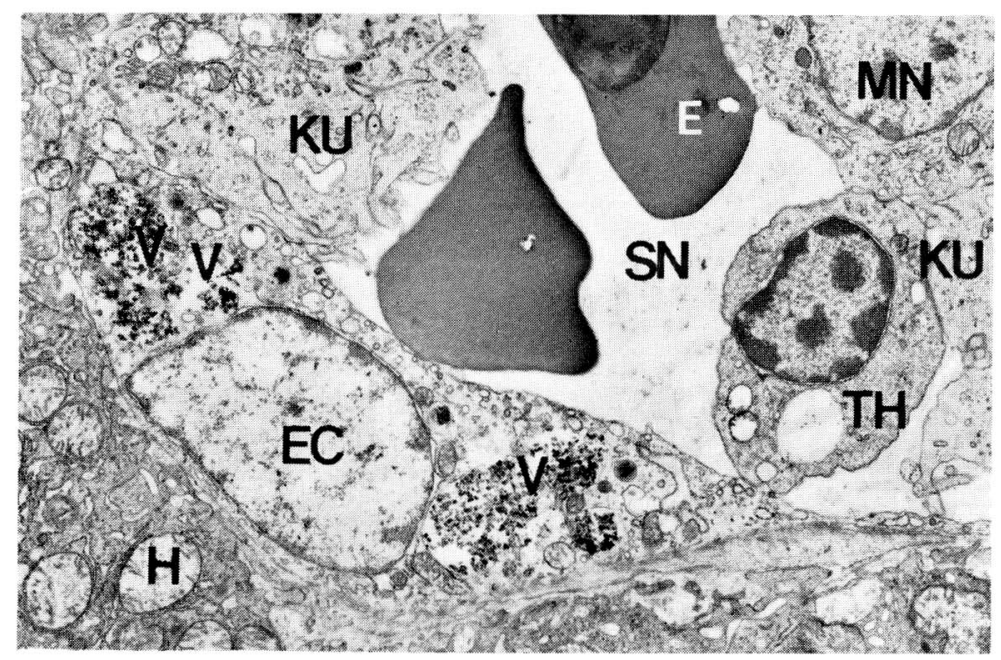

Fig. 13. Endothelial perikaryon (EC), $4 \mathrm{hr}$ after India ink perfusion. The major area of the perikaryonal cytoplasm is occupied by vacuoles $(V)$ filled with carbon particles. $E$ erythrocyte, $S N$ sinusoid, $H$ hepatocyte, $K U$ Kupffer cells, $M N$ monocyte, $T H$ thrombocyte. $\times 6,000$

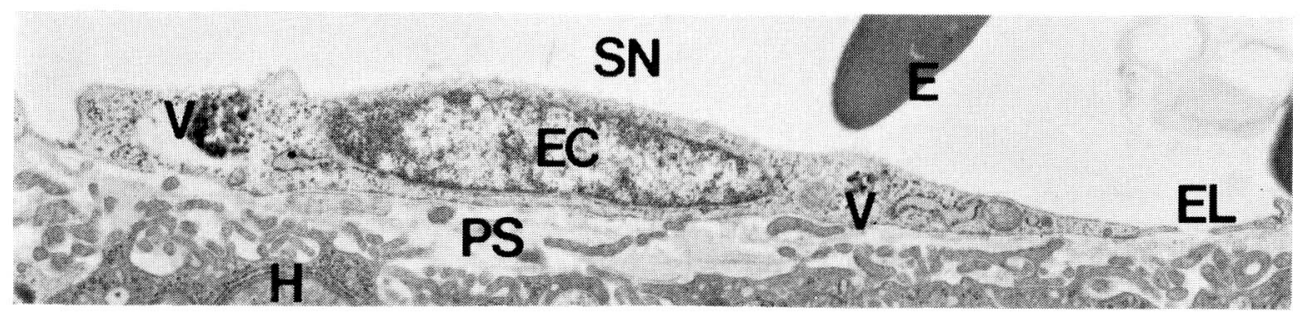

Fig. 14. Endothelial perikaryon (EC), $48 \mathrm{hr}$ after India ink perfusion. On either side of the nucleus a small vacuole $(V)$ filled with the particles is present. $E$ erythrocyte in sinusoid (SN), $E L$ endothelial extension, $H$ hepatocyte, $P S$ Disse's space. $\quad \times 10,000$

It projects its cell body covered by filopodial projections into the sinusoidal lumen, giving the appearance of a Kupffer cell, although it stored no particles in the cytoplasm at $48 \mathrm{hr}$ after India ink perfusion.

Like intralobular solitary macrophages, those in the ly mphoid tissues of the chicken livers also took up India ink particles in the later stages after perfusion. At $1 \mathrm{hr}$ after perfusion of India ink, a few macrophages in the lymphoid tissue endocytosed particles, to store them in several small vacuoles (Fig. 20a). At $48 \mathrm{hr}$, almost all macrophages ingested large vacuoles (Fig. 20b). Observations of this reaction suggest that in the lymphoid tissues of the chicken liver, macrophages may exceed lymphocytes in numher. In this later stage after the India ink perfusion, mitotic figures-probably of macrophages - were occasionally indentified in the lymphoid tissue, in contrast to their absence among solitary macrophages scattered in the hepatic lobules. In agreement with the findings in Kupffer cells, mitotic macrophages showed cell organelles dislocated at the two opposite poles of the cell (Fig. 21a) or in the periphery of the cytoplasm (Fig. 21b).

Figure 22a shows a macrophage observed at $48 \mathrm{hr}$ after the India ink perfusion. 


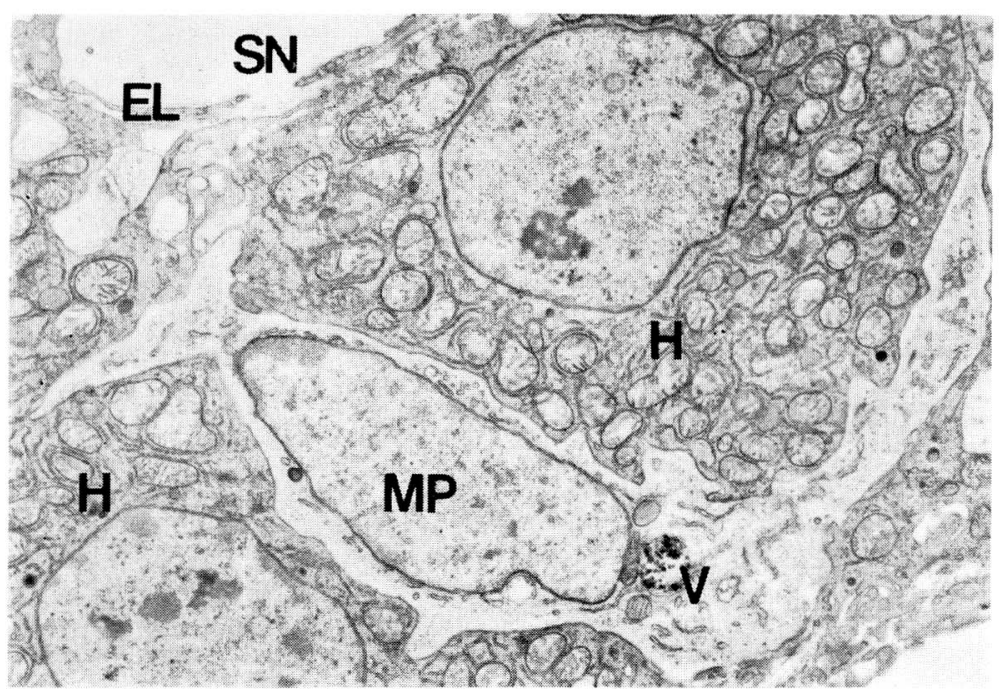

Fig. 15. Solitary macrophage $(M P)$ elongated between hepatocytes and extending cytoplasmic processes, $4 \mathrm{hr}$ after India ink perfusion. A small phagocytic vacuole $(V)$ filled with the carbon particles is found close to the nucleus. Short cisterns of RER are distributed in the cytoplasm. EL endothelial lining of sinusoid (SN), $H$ hepatocyte. $\times 6,000$

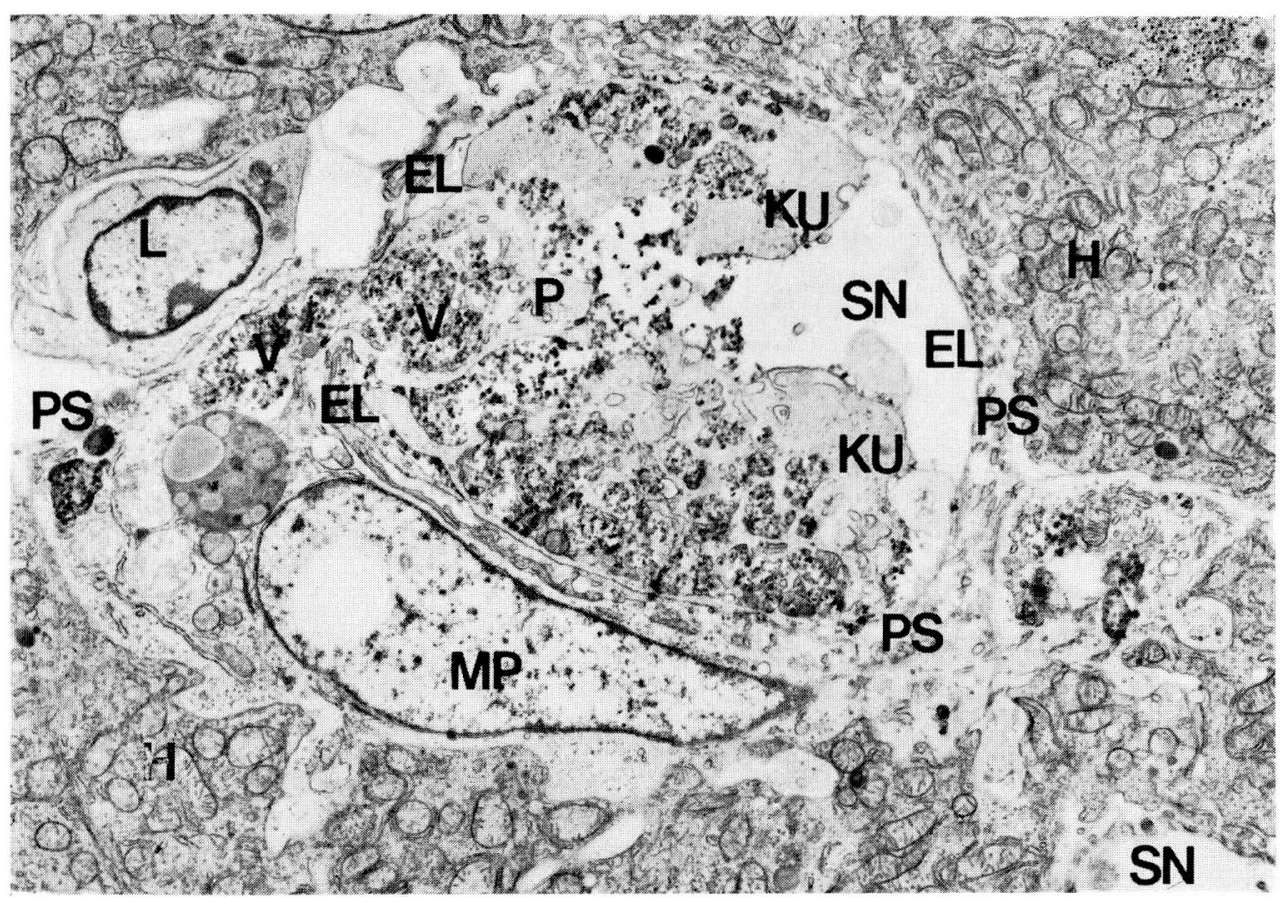

Fig. 16. Solitary macrophage $(M P)$ in the Disse's space ( $P S)$ sending a thick cytoplasmic process $(P)$ through the endothelial lining ( $E L)$ into the sinusoid ( $S N)$ between two parts of the Kupffer cell $(K U)$. At 30 min after India ink perfusion, the cytoplasmic process contains the carbon particles in a large vacuole $(V)$; the particles are also seen in a vacuole $(V)$ and in a lysosome of the adjacent part of the cell body. $H$ hepatocyte, $L$ lymphocyte. $\quad \times 6,000$ 


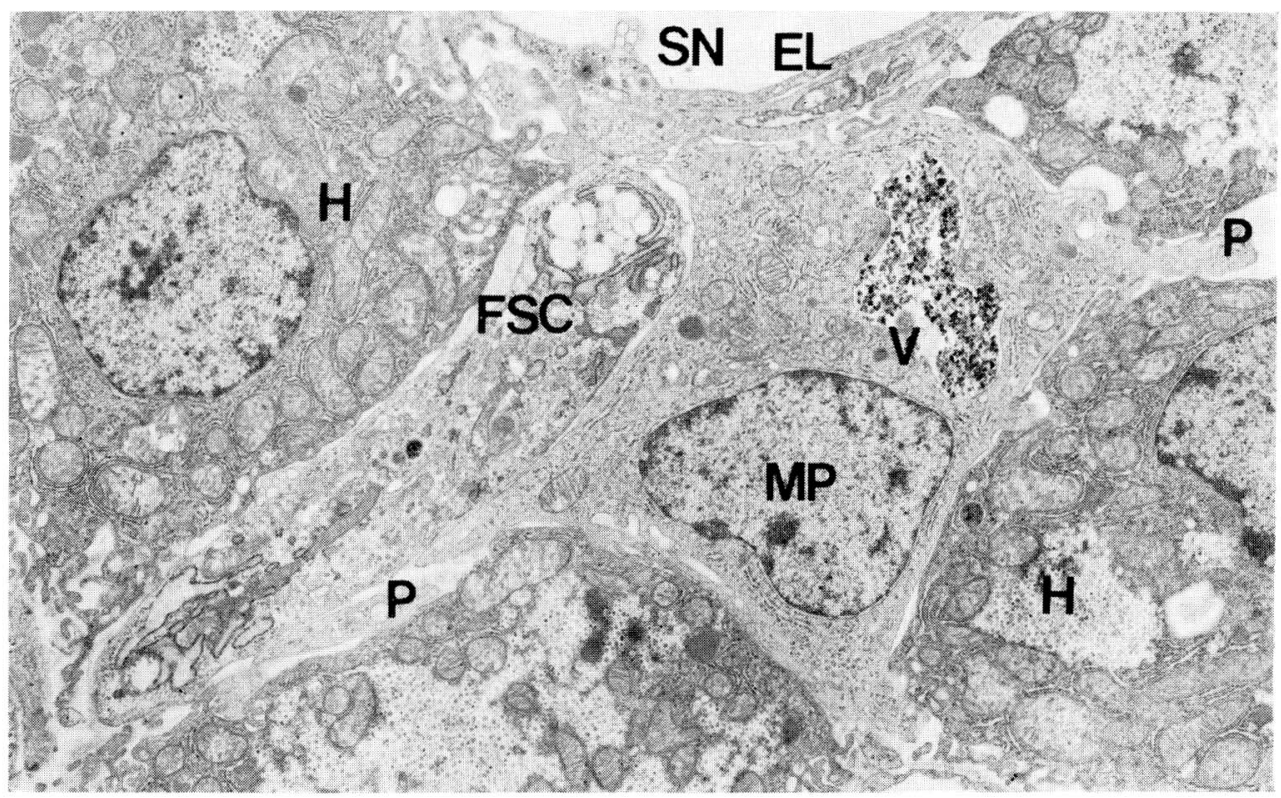

Fig. 17. Solitary macrophage $(M P)$ between hepatocytes $(H)$ and an Ito cell (FSC) with cytoplasmic processes $(P), 48 \mathrm{hr}$ after the India ink perfusion. The solitary macrophage possesses a large phagocytic vacuole $(V)$ filled with carbon particles, well-developed RER, several mitochondria and lysosomes. EL endothelial lining of sinusoid ( $S N) . \quad \times 6,800$

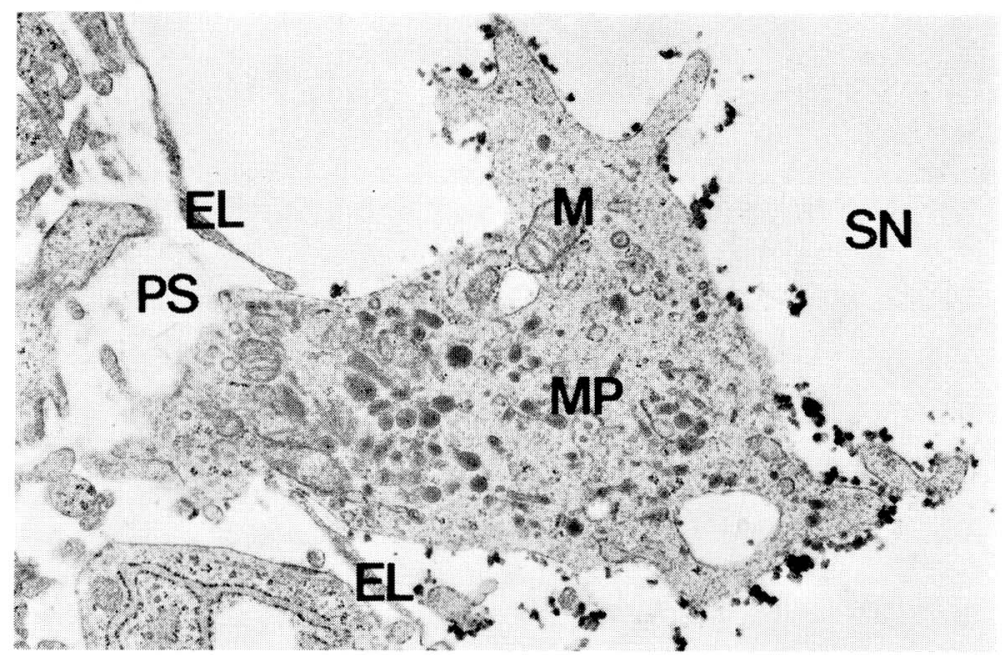

Fig. 18. Migrating solitary macrophage (MP), 20 min after India ink perfusion. The major part of the cytoplasm is displaced through the endothelial lining ( $E L$ ) into the sinusoid ( $S N)$, projecting many pseudopodia. The cytoplasm contains many lysosomes and large mitochondria $(M)$. This solitary macrophage adsorbs carbon particles to the plasma membrane only in the part exposed to the sinusoid while no particles adhere to the plasma membrane of the minor part remaining in the Disse's space (PS). $\quad \times 13,300$ 


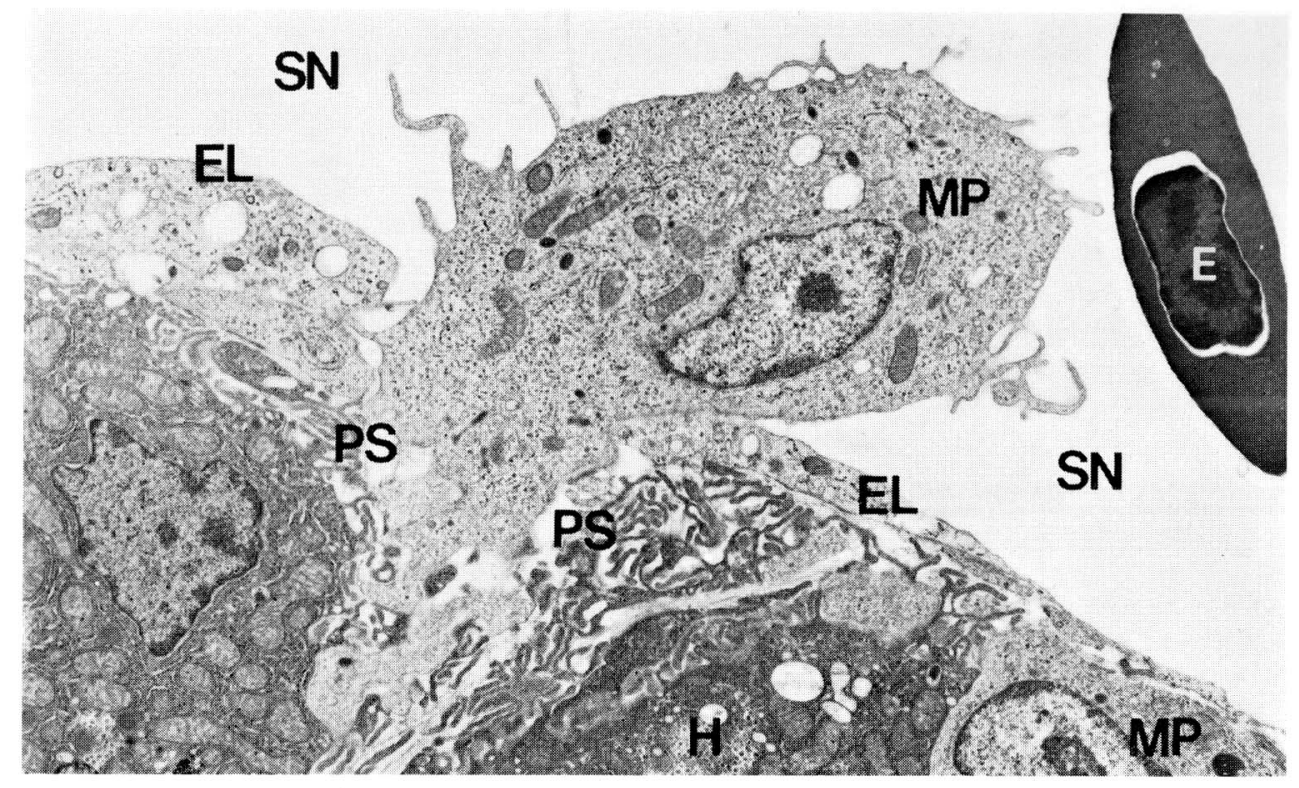

Fig. 19. Migrating solitary macrophage (MP) present under the same conditions as those depicted in Figure 18. This macrophage observed at $48 \mathrm{hr}$ after the India ink perfusion shows neither the sign of endocytosis nor adsorption of the particles. It projects many pseudopodia. $E$ erythrocyte in sinusoid (SN), EL endothelial lining, $H$ hepatocyte, $P S$ Disse's space with many microvilli of hepatocytes. $\times 6,800$

The cell is rich in free ribosomes, RER, large mitochondria and small lysosomes. Containing a large vacuole filled with India ink particles, this cell is apparently on its way of migration through a pore of the endothelial lining into a sinusoid. The major part of the cell body, already contained in the sinusoid, is provided with well-developed pseudopodia, suggesting the transformation of the cell into a Kupffer cell.

In the chicken liver, Ito cells were occasionally found to ingest a very small amount of the India ink particles into small vacuoles or lysosomes in later stages after perfusion (at 4 and $48 \mathrm{hr}$ ) (Fig. 23a, b).

\section{DISCUSSION}

Concerning the origin of the Kupffer cell, numerous authors have discussed from different view points as recently summarized by Iто (1986). Roughly three different views have been proposed: 1 ) the idea that Kupffer cells are increased and supplemented by self-proliferation (WISSE, 1974), 2) the "theory of the mononuclear phagocyte system" proposed by VAN FURTH et al. (1977, 1982), maintaining that all mononuclear phagocytes, including Kupffer cells, are derived from circulating monocytes; and 3) the concept of a "dual origin of Kupfler cells" proposed by Bouwens and W Isse (1982), presuming both the local self-proliferation of Kupffer cells and the influx of circulating monocytes into the sinusoid to there transform into Kupffer cells. In the present study we examined the uptake (endocytosis) of India ink in sinusoidal cells, extrasinusoidal macrophages and in macrophages (phagocytic reticular cells) of the lymphoid tissues. The last cells have been known by many authors to occur in chicken livers (KANESADA, 1956a, b; ITO 


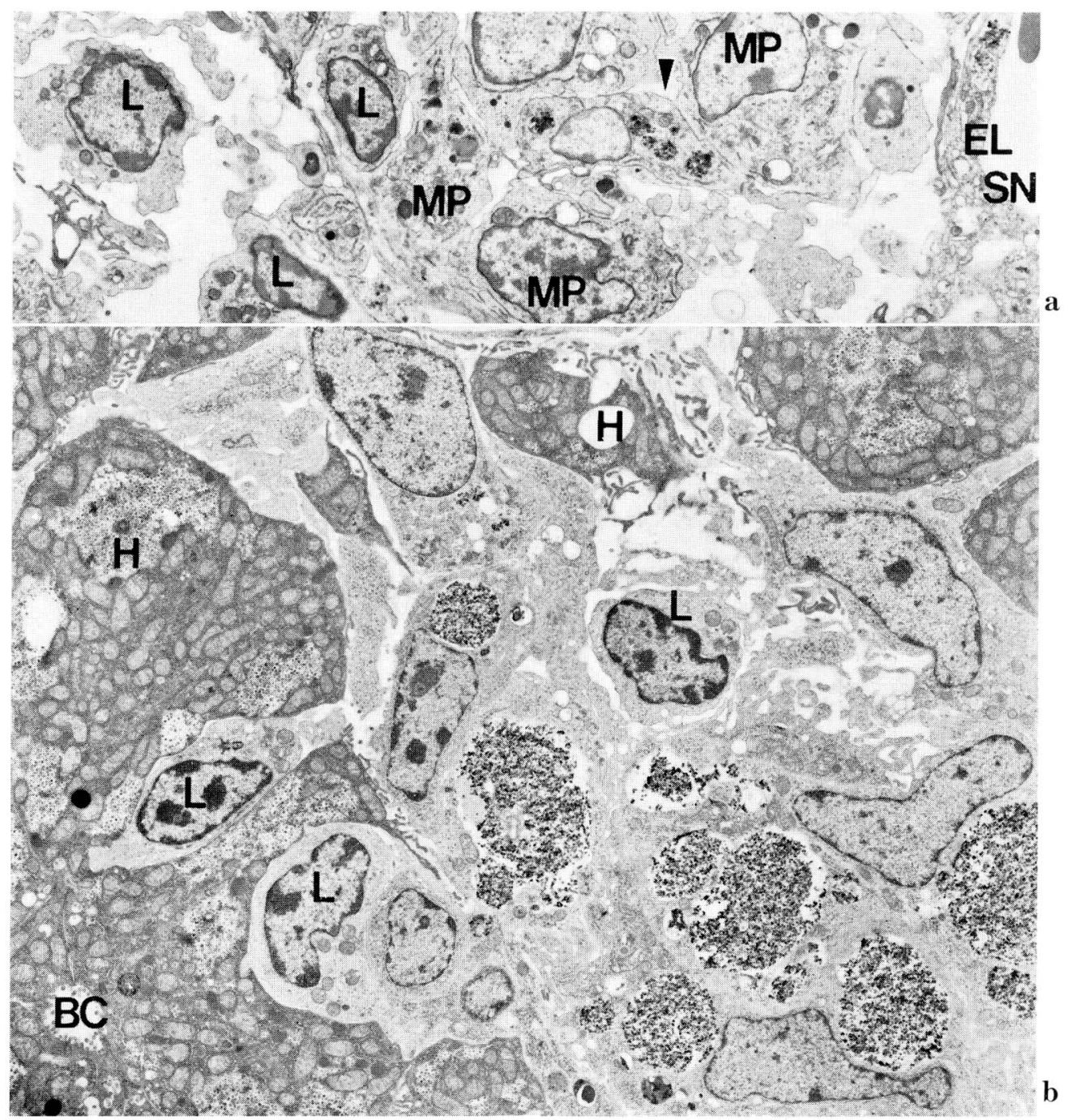

Fig. 20. a and b. Lymphoid tissues in chicken liver parenchyme. a. At 4 hr after India ink perfusion, only one macrophage (arrowhead) among many macrophges (MP) contains several small phagocytic vacuoles filled with carbon particles, EL endothelial lining of sinusoid $(S N), L$ lymphocyte. b. At $48 \mathrm{hr}$ after India ink perfusion, the majority of macrophages store large amounts of the carbon particles in large phagocytic vacuoles. Note that in the lymphoid tissue of the chicken liver, lymphocytes $(L)$ comprise only a minor population. $B C$ bile canalicule, $H$ hepatocytes. $\mathrm{a}, \mathrm{b}: \times 2,000$

et al., 1960; Kitagawa, 1960; Tanaka, 1960; Umahara, 1963). That the vital staining not only stains the cells of the reticuloendothelial system (RES) but also stimulates them to mitotically divide has been established by earlier authors (Schmidt, G., 1931; Schmid , F. C., 1956, 1959). In the present study it has also been confirmed that several phagocytic cells are able to divide simultaneously with the uptake of India ink particles, enabling us to reveal the mitotic activity of several phagocytic cells without the application of such division-stimulating agents as estradiol, Zymosan and others. 


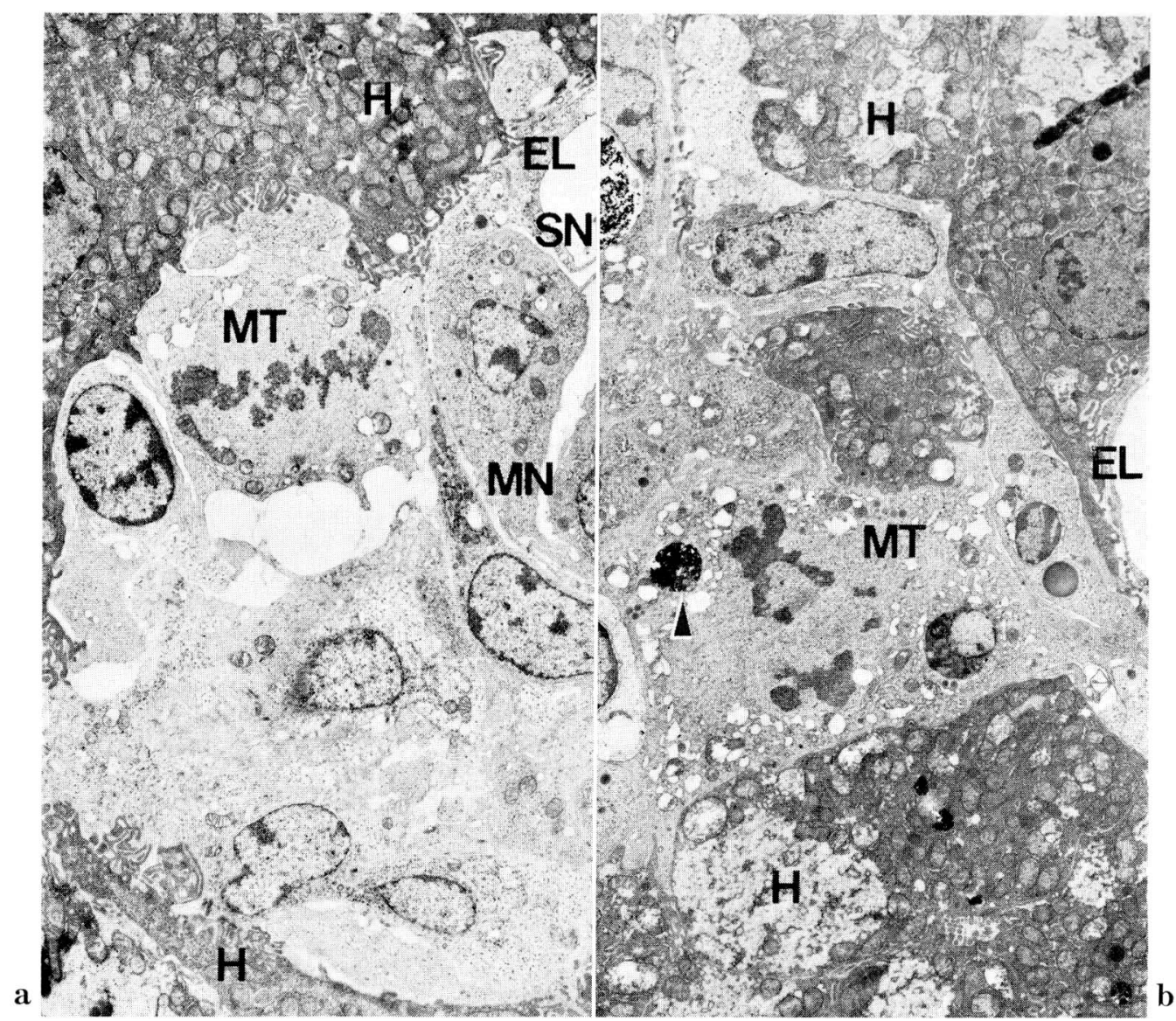

Fig. 21. a and b. Lymphoid tissue in the chicken liver parenchyme, $48 \mathrm{hr}$ after India ink perfusion. a. A mitotic figure $(M T)$ of the macrophage is shown in which cell organelles are displaced at opposie poles of the cell. Other cells store no carbon particles. EL endothelial lining of sinusoid ( $S N), H$ hepatocytes, $M N$ monocyte in sinusoid. b. A mitotic figure (MT) of the macrophage is shown in which cell organelles, a phagocytic vacuole filled with carbon particles (arrowhead) and a lysosome are displaced to the peripheral part. EL endothelial lining, $H$ hepatocytes. a, b: $\times 4,000$

\section{Reactions of the so-called sinusoidal cells}

The most striking and earliest reactions against intravenously introduced India ink were shown by Kupffer cells. At 15 to 30 min after the perfusion, India ink particles adhered mainly to the sinusoidal surface of the Kupffer cells. A few particles were taken up by the bristle-coated pits and then pinched off to make pinocytic vesicles of variable sizes containing the particles. However, the majority of the particles were taken up via plasma membrane indentations, penetrating the interior of the cytoplasm. The quantitative relation between these two manners of particle uptake was unknown, but the particles taken up in both ways filled the vacuoles densely occupying the endoplasm. The participation of the worm-like structures in the uptake of the particles was obscure, contrary to the view of WISSE (1974). At 30 min after perfusion, the amounts of India ink particles stored in the endoplasmic vacuoles attained the maximum. At 4 and $48 \mathrm{hr}$, the particle-containing vacuoles were gradually diminished, 


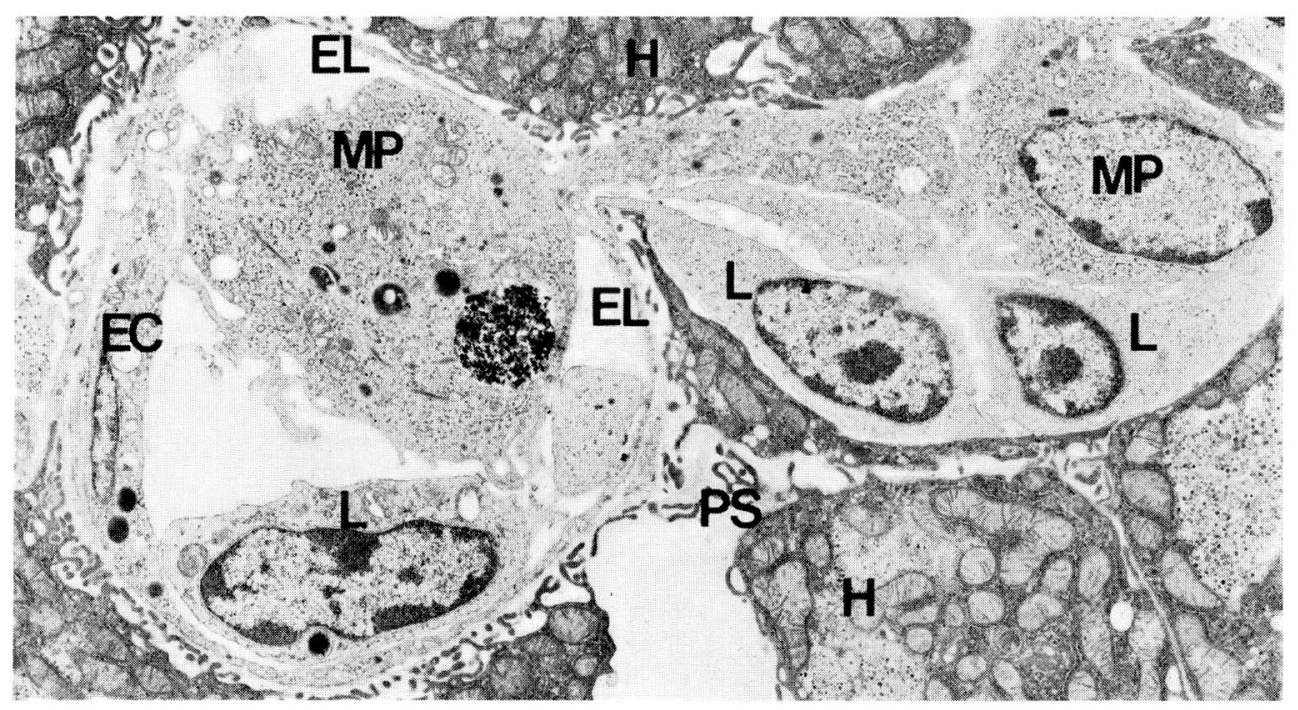

Fig. 22. Migrating macrophage (MP) from the lymphoid tissue on the right side into the sinusoid $(S N)$ on the left side through sinusoidal endothelial lining (EL), $48 \mathrm{hr}$ after India ink perfusion. The main part of the macrophage displaced in the sinusoid contains a large particlefilled vacuole and projects pseudopodia. $E C$ endothelial perikaryon, $H$ hepatocytes, $L$ lymphocyte, $P S$ Disse's space. $\quad \times 2,000$

and at $48 \mathrm{hr}$ the mitotic figures of the Kupffer cells were encountered not rarely in the sinusoid, indicating their self-proliferation in accordance with the results of the WISSE's experimental study with Thorotrast (WISSE, 1974).

Sinusoidal endothelial cells started to take up India ink particles as early as the Kupffer cells, but attachment of particles to their surface was not recognized. At $30 \mathrm{~min}$ after perfusion of the India ink, a few particles were taken up by pinocytic process into the perikaryonal cytoplasm to be stored in the existing macropinocytic vacuoles (vesicles) of Wisse (1972). Cytological signs suggesting that many coated pits and vesicles were involved in the particle uptake were not available along the sinusoidal surface of the perikaryon (Онат A et al., 1982). From 1 hr after perfusion, the particles stored in the macropinocytic vacuoles were gradually increased, and enlarged vacuoles filled with the particles occupied the major area of the perikaryonal cytoplasm at $4 \mathrm{hr}$, indicating that lysosomes might have ingested the particles. Different from Kupffer cells, the only occasional endothelial cells were holding the particle-filled small vacuoles at $48 \mathrm{hr}$. The amount of activity in taking up India ink was thought to be lower in the sinusoidal endothelial cells than in the Kupffer cells. Widmann et al. (1972) described how there were differences between endothethelial and Kupffer cell not only in the endogenous peroxidase activity, but also in carbon particle adsorbing and ingesting abilities of these cells. During the stimulation by India ink perfusion, the sinusoidal endothelium showed neither tendency to either transform into the Kupffer cell or to divide mitotically.

Ito cells have been believed non-phagocytic in nature ever since a light microscopic study carried out in rabbits intravenously perfused with India ink and carmine particles (Satsuki, 1952). The present electron microscopic study, however, demonstrated a slight ability for chicken Ito cells to ingest India ink particles. In his comprehensive electron microscope study on the mouse liver, Yамамото (1975) pointed out, that Ito cells could occasionally endocytose Thorotrast particles, as fibroblasts in 


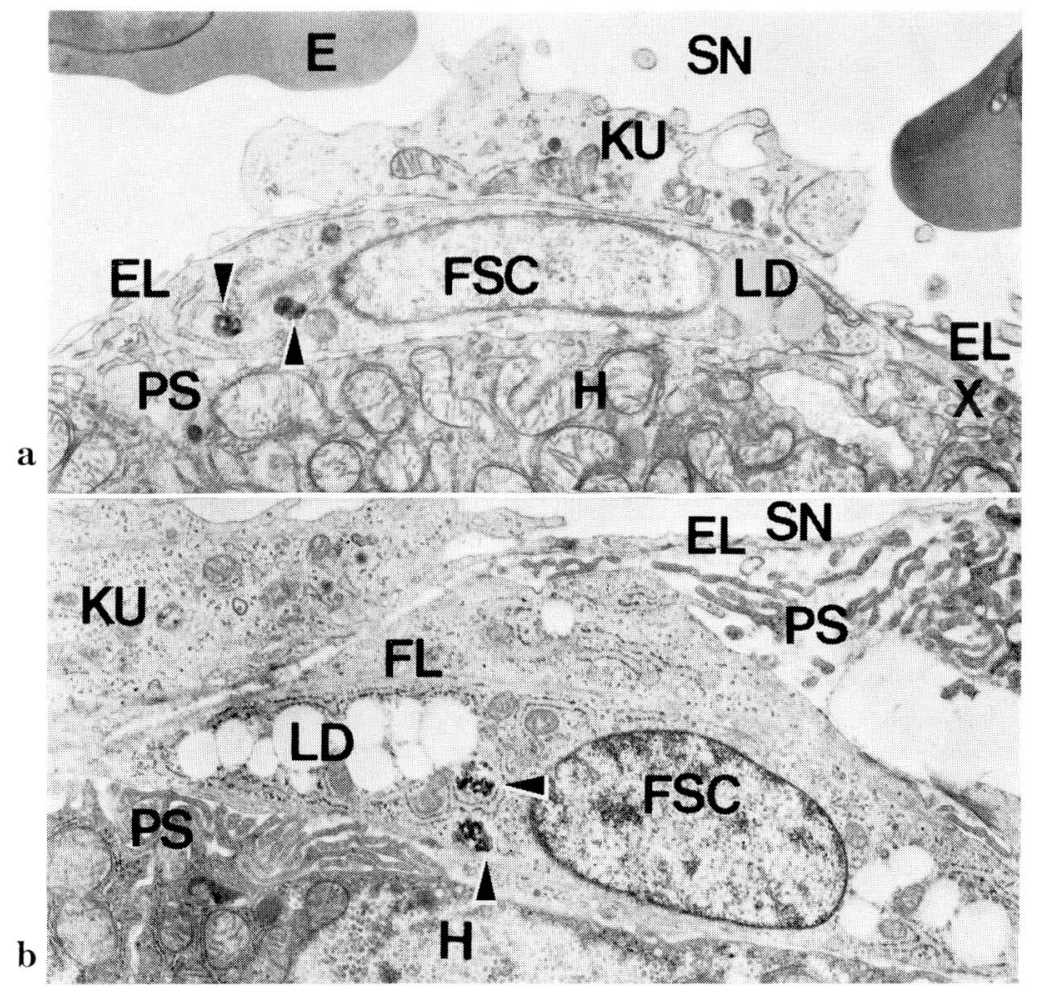

Fig. 23. a and b. Ito cells (FSC); a : $4 \mathrm{hr}, \mathbf{b}: 48 \mathrm{hr}$ after India ink perfusion. Ito cells are located in the Disse's spaces (PS) and possess cisterns of RER, lipid droplets ( $L D)$, small mitochondria and some microfilaments $(F L)$. A very small amount of carbon particles is stored in small phagocytic vacuoles (arrowheads in b) or in lysosomes (arrowheads in a). E erythrocyte in sinusoid (SN), EL endothelial lining, $H$ hepatocytes, $K U$ Kupffer cell, $X$ subendothelial process of Ito cell. a, b: $\times 8,000$

the Glisson's sheath did. Although the amount of the particles endocytosed by chicken Ito cells was extremely small as compared with the quantity of particles phagocytosed in the Kupffer and endothelial cells, it seemed to not be completely correct to take Ito cells for absolutely non-phagocytic cells. On the contrary, Ito cells must be regarded as inactive phagocytic cells as appropriately pointed out by Yамамото (1975). WidmanN et al. (1972) described the Ito cells of rat livers as totally non-phagocytic and negative in endogenous peroxidase activity. No mitotic division was found in the Ito cells.

\section{Reactions of the solitary macrophages and macrophages in lymphoid tissue}

Extrasinusoidal solitary macrophages scattered in the avian liver parenchyme were described for the first time by Оната et al. (1982); these cells were most frequently detected in the chicken liver. They were found in the interhepatocytic and Disse's spaces, often projecting their cytoplasmic processes so far as to enter the sinusoidal lumen beyond the Disse's spaces. The occurrence of lymphoid tissues of either of the infiltration type or the nodular type in the chicken and other avian livers has been reported in light microscopic studies by Kanesada (1956a, b), Ito et al. (1960), KitaGAw A (1960), TAnAKA (1960) and Umahara (1963), accordingly that the lymphoid tissue has 
come to be regarded today as physiological and usual structure in the avian liver. The lymphoid tissues observed in this study were of the infiltration type and composed of lymphocytes and reticular cells, the latter resembling the above-described solitary macrophages in ultrastructural properties. These reticular cells and macrophages many be referred to as phagocytic reticular cells or macrophages.

The intravenous perfusion of India ink gave evidence that the solitary extrasinusoidal macrophages scattered in the chicken hepatic parenchyme were genuine phagocytes with endocytic activity, storing ingested particles in phagocytic vacuoles near the nucleus. As they were separated from the sinusoid by the endothelium, the endocytosis of carbon particles was delayed. When they projected a cytoplasmic process through the endothelial lining into the sinusoid, however, large amounts of particles could be taken up earlier by this process. At a later stage $(48 \mathrm{hr})$ after the perfusion, almost all intralobular solitary macrophages stored particles regardless of their contact to the sinusoidal lumen. The above finding that the solitary macrophages in the chicken liver parenchyme have a tendency to project a cytoplasmic process into the sinusoid seems to imply two functions of the macrophages; one being the communication of the cells with the sinusoidal contents, and other the migration of the cells into the sinusoid. These two functions seem to be stimulated by the intravenous perfusion of India ink; especially the frequency of the migration of solitary macrophages into the sinusoid through the endothelial lining seemed to increase after the India ink perfusion. Some of the macrophages entered their major cell portions into the sinusoid, exhibiting characteristic features of the Kupffer cells, e.g., numerous lysosomes, projection of many pseudopodia and attachment of India ink particles on the plasma membrane. This finding strongly supports the assumption that the solitary macrophages in the parenchyme may transform into Kupffer cells after migration into the sinusoid. Ever since TANUma and Iто (1978) discovered, during their electron microscope study on the bat liver, the migration of macrophages from the parenchyme into the sinusoid, research workers of our department have confirmed this phenomenon in the liver of several vertebrate species (Tanuma, Оhata and Ito, 1981 in kitten liver; Tanuma, Оhata and Iто, 1982 in flat fish liver; Оната, Tаnuma and Iто, 1982 in avian liver; Tanuma, Оната and ITo, 1983 in monkey liver). The migration of intraparenchymal macrophages into the sinusoid to transform into Kupffer cells is thus regarded as a phenomenon prevalent among vertebrate livers.

In the lymphoid tissue present in the chicken liver, a few phagocytic reticular cells or macrophages, like the intralobular solitary macrophages, commenced to phagocytose India ink particles at a later stage ( $4 \mathrm{hr}$ ), storing sparse particles in a few small vacuoles, while at $48 \mathrm{hr}$ after the perfusion almost all macrophages stored large amounts of the particles in large vacuoles. A glance of the lymphoid tissue at $48 \mathrm{hr}$ after the perfusion surprised us by the fact that the majority of the cell components of the lymphoid tissue were macrophages, while the minority were lymphocytes. In contrast to the solitary macrophages scattered in the parenchyme which never showed mitotic figures, several macrophages in the lymphoid tissue revealed mitosis, as the sinusoidal Kupffer cells did, at $48 \mathrm{hr}$ after the India ink perfusion. For the delayed occurrence of the endocytosis against the carbon particles in the macrophages both in the parenchyme and in the lymphoid tissue, their location being separated from the sinusoidal lumen by the endothelium seems responsible. The fenestrae of the endothelial lining are thought to control the free passing of the carbon particles, although these measure about $50 \mathrm{~nm}$ in diameter on average and are smaller in size than the endothelial fenestrae. In this study we were only rarely able to find carbon particles in the Disse's spaces in spite of 
laborious searching. The direct migration of a macrophage from the lymphoid tissue into the sinusoid was also rarely confirmed at any stages after the India ink perfusion.

From the above findings we came to the conclusion that the location where the intraparenchymal macrophages mitotically proliferate must be the intralobular lymphoid tissues. From this location the proliferated macrophages are believed to migrate into the parenchyme of the liver to supplement the solitary macrophages which might be diminished gradually in consequence of the migration through the endothelial lining into the sinusoid to replenish the Kupffer cells, although these might also be supplemented by self-proliferation and further by transformation from the monocytes flowing into the sinusoid as discussed in the succeeding part of this work.

It seems thus reasonable to summarize that the macrophages present in the chicken liver lymphoid tissue always supplement the solitary macrophages in the parenchyme. Also in other mammalian livers (bat: Tanuma and Ito, 1978; kitten: Tanuma, Oнata and Iто, 1981; crab-eating monkey: Tалима, Оната and Iто, 1983) has migration of the intraparenchymal macrophages into sinusoids been substantiated. These macrophages in the mammalian hepatic parenchyme were presumed to have originated from the macrophages detected in the parenchyme of the fetal liver. Naito $(1975,1976)$ carried out the electron microscopic cytochemical studies on the fetal rat liver at 12-18 days of pregnancy, and demonstrated, in its parenchyme, macrophages which might transform into Kupffer cells after migration into the sinusoid and attachment to its endothelial lining. The macrophages in the fetal liver parenchyme are presumed to be maintained by mitotic division until, when in the adult liver they furnish Kupffer cells throughout life.

\section{REFERENCES}

Bouwens, L. and E. Wisse: On the dual origin of the Kupffer cell. In (ed. by) D. L. Knook and E. Wisse: Sinusoidal liver cells. Elsevier Biomedical Press, Amsterdam, 1982 (p. 165-172).

Furth, R. van, R. W. Crofton and M. M. C. Diesselhoff-den Dulk: The bone marrow origin of Kupffer cells. In (ed. by) E. Wisse and D. L. Knook: Kupffer cells and other liver sinusoidal cells. Elsevier Biomedical Press, Amsterdam, 1977 (p. 471-480).

Furth, R. van and D. Blusse van oud Alblas : New aspects on the origin of Kupffer cells. In (ed. by) D. L. Knook and E. Wisse: Sinusoidal liver cells. Elsevier Biomedical Press, Amsterdam, 1982 (p. 173-183).

Ito, T.: Structure and function of the fat-storing cell in the liver-A review. (Japanese text with English abst.) Acta anat. nippon. 53: 393-422 (1978).

-: Liver sinusoid, perisinusoidal space and sinusoidal cells. (In Japanese). In: Human histology. Vol. 4, part 6. Asakura Medical Press, Tokyo, 1986 (in press).

Ito, T., Y. Tanaka and M. Nemoto: Histogenetische Untersuchungen über die Leber des Huhnchens während der Brutung und nach der Ausbrutung mit besonderer Berücksichtigung der Fettspeicherungszellen (fat-storing cells) und der Mitochondrien der Leberzellen. (Japanese text with German abst.) Arch. histol. jap. 19: 565-595 (1960).

Kanesada, A.: Lymphoid tissues occurring in the liver and bone marrow of reptiles and birds. (Japanese text with English abst.) Arch. histol. jap. 10: 471-481 (1956a).

-: Postnatal development of lymphoid tissues in the liver and bone marrow in white leghorn chickens. (Japanese text with English abst.) Arch. histol. jap. 10: 525-529 (1956b).

Kitagawa, T.: Histologische und cytologische Untersuchungen über die Hühnerleber nebst Bemerkungen der Fettspeicherungszellen (fat-storing cells). (Japanese text with German abst.) Arch. histol. jap. 18: 495-540 (1960). 
Naito, M.: Electron microscopical study on the origin of Kupffer cells. Recent Adv. RES Res. 15: 76-82 (1975).

: Morphology and origin of the Kupffer cell. (In Japanese). J. Jap. R.E.S. 16: 25-42 (1976).

Ohata, M., Y. Tanuma and T. Ito: Electron microscopic study on avian livers with special remarks on the fine structure of sinusoidal cells. Okajimas Fol. anat. jap. 58: 325-368 (1982).

Satsuki, S.: Untersuchungen über das Speicherungsvermögen der "Fettspeicherungszellen" von Leber durch die Karmin- und Tuschinjektion. (Japanese text with German abst.) Arch. histol. jap. 3: 449-456 (1952).

Schmidt, F. C.: Über das Vorkommen von Kupfferschen Sternzellen und Fettspeicherzellen in der Leber von Fischen (Cyprinus carpio). Z. mikrosk.-anat. Forsch. 62: 487-520 (1956).

- : Vorkommen und Verhalten von Sternzellen der Leber des Aales und ihre Beziehung zum reticuloendothelialen System. Z. Zellforsch. 49: 401-417 (1959).

Schmidt, G.: $\quad$ Die vitale Trypanblauspeicherung bei Salamanderlarven. Z. Anat. 96: 68-83 (1931).

Tanaka, Y.: Cytologische und histologische Untersuchungen über die Leber bei den Sperlingen mit besonderer Berücksichtigung der jahreszeitlichen Veränderungen und der Fettspeicherungszellen (fat-storing cells). (Japanese text with German abst.). Arch. histol. jap. 19: 145-188 (1960).

Tanuma, Y. and T. Ito: Electron microscope study on the hepatic sinusoidal wall and fat-storing cells in the bat. Arch. histol. jap. 41: 1-39 (1978).

Tanuma, Y., M. Ohata and T. Ito: An electron microscopic study of the kitten liver with special reference to fat-storing cells. Arch. histol. jap. 44: 23-49 (1981).

_- Electron microscopic study on the sinusoidal wall of the liver in the flatfish, Kareius bicoloratus: Demonstration numerous desmosomes along the sinusoidal wall. Arch. histol. jap. 45: 453-472 (1982).

: Electron microscopic studies on the sinusoidal cells in the monkey liver. Arch. histol. jap. 46: 401-426 (1983).

Umahara, Y.: Histologische Studien über die Leber von Vögeln nebst Bemerkungen der Fettspeicherungszellen (fat-storing cells). (Japanese text with German abst.) Arch. histol. jap. 23: 252282 (1963).

Widmann, J. J., S. R. Cotran and H. D. Fahimi : Mononuclear phagocytes (Kupffer cells) and endothelial cells. Identification of two functional cell types in rat liver sinusoids by endogenous peroxidase activity. J. Cell Biol. 52: 159-170 (1972).

Wisse, E. : An ultrastructural characterization of the endothelial cell in the rat liver sinusoid under normal and various experimental conditions, as a contribution to the distinction between endothelial and Kupffer cells. J. Ultrastr. Res. 38: 528-562 (1972).

-: Kupffer cell reactions in rat liver under various conditions as observed in the electron microscope. J. Ultrastr. Res. 46: 499-520 (1974).

Yamamoto, M.: Ultrastructure and function of Ito cell (fat-storing cell) in the liver. (Japanese text with English abst.) Med. J. Hiroshima Univ. 23: 245-274 (1975).

\author{
大畑まさ子 \\ 干173 東京都板橋区加賀 2-11-1 \\ 帝京大学医学部 \\ 解剖学第一講座
}

Dr. Masako OHAtA

Department of Anatomy

Teikyo University School of Medicine

Kaga 2-11-1, Itabashi-ku

Tokyo, 173 Japan 